\title{
St. Kitts and Nevis-First Review Under the Stand-By Arrangement and the Financing Assurances Review, and Request for Waivers of Applicability and Modification of Performance Criterion-Staff Report and Press Release
}

The following documents have been released and are included in this package:

- $\quad$ The staff report for the First Review Under the Stand-By Arrangement and the Financing Assurances Review, and Request for Waivers of Applicability and Modification of Performance Criterion, prepared by a staff team of the IMF, following discussions that ended on December 12, 2011 with the officials of St. Kitts and Nevis on economic developments and policies. Based on information available at the time of these discussions, the staff report was completed on January 12, 2012. The views expressed in the staff report are those of the staff team and do not necessarily reflect the views of the Executive Board of the IMF.

- $\quad$ A Press Release.

The policy of publication of staff reports and other documents allows for the deletion of market-sensitive information.

\author{
Copies of this report are available to the public from \\ International Monetary Fund • Publication Services \\ $70019^{\text {th }}$ Street, N.W. • Washington, D.C. 20431 \\ Telephone: (202) 623-7430 • Telefax: (202) 623-7201 \\ E-mail: publications@imf.org Internet: http://www.imf.org
}

\section{International Monetary Fund Washington, D.C.}




\title{
INTERNATIONAL MONETARY FUND
}

\section{ST. KITTS AND NEVIS}

\section{First Review Under the Stand-By Arrangement and the Financing Assurances Review, and Requests for Waivers of Applicability and Modification of Performance Criterion}

\author{
Prepared by the Western Hemisphere Department in Consultation with Other Departments
}

\author{
Approved by David Vegara and Jan Kees Martijn
}

January 12,2012

\section{Executive Summary}

Context. St. Kitts and Nevis' economic activity has remained flat in 2011, reflecting the more adverse global environment. Despite the weaker and more volatile environment, the authorities have steadfastly implemented their home-grown economic program and begun to achieve positive results. The outlook remains favorable, supported by FDI-related construction projects and an improvement in tourism activity. However, uncertainty regarding the global economic recovery highlights increasing downside risks.

Stand-By Arrangement (SBA). On July 27, 2011, the Executive Board approved a 36-month SBA for St. Kitts and Nevis for SDR 52.51 million (590 percent of quota) to support the program (Country Report No. 11/270). SDR 22.15 million (248.9 percent of quota) was disbursed upon Board approval. A second tranche of SDR 11.47 million will be made available upon completion of this review.

Program Performance. All quantitative performance criteria and most structural benchmarks for end-September 2011 were met. The three delayed structural benchmarks, which are proposed as prior actions for the first review, were completed before the end of December 2011. In line with expectations under the program supported by the SBA, the authorities have started the process of a comprehensive debt restructuring, including a debt-land swap. The authorities requested waivers of applicability for quantitative performance criteria (PC) for end-December 2011 and modification of the $\mathrm{PC}$ on the budget expenditure arrears accumulation.

Review. In the attached supplementary Letter of Intent and Memorandum of Economic and Financial Policies, the authorities elaborate on their policies for 2012, which are in line with the program, and proposed corresponding quantitative performance criteria and structural benchmarks. Staff supports the authorities' request for the completion of the first program and financing assurances reviews under the SBA.

Mission. The staff team comprised Alfred Schipke (Head), Mr. K. Nassar, Ms. S. Ogawa (all WHD), Ms. A. Holland (MCM), and Ms. S. Jahan (SPR); it was assisted by Mr. W. Samuel (Regional Resident Representative). During November 28-December 12, 2011, the mission met with the Prime Minister/Finance Minister, the Cabinet, the ECCB Governor and senior staff, as well as other senior Government officials and representatives of the private sector. Mr. G. Tsibouris (WHD) and Mr. M. Sajkunovic (OED) attended the final meetings. 
Executive Summary 1

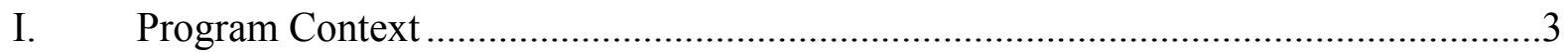

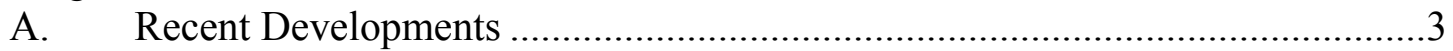

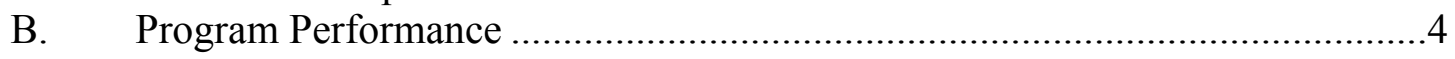

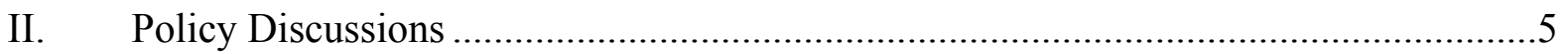

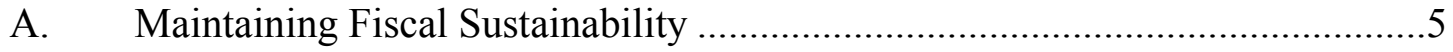

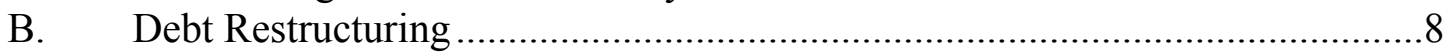

C. Reducing Financial Sector Vulnerabilities ................................................

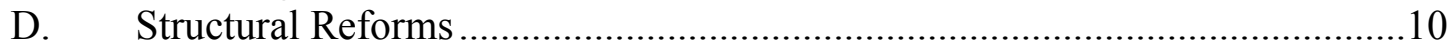

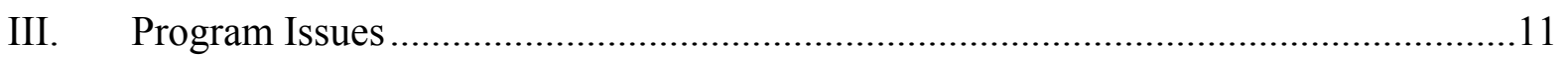

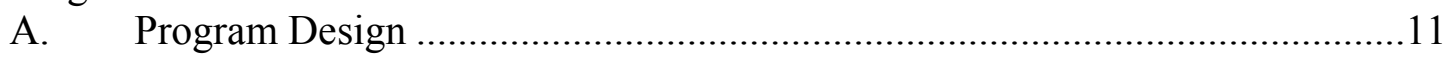

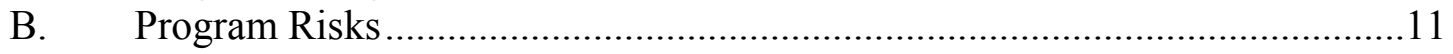

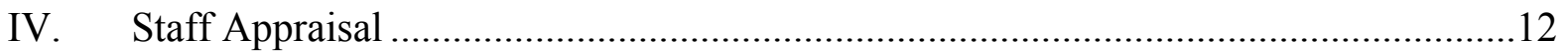

Boxes

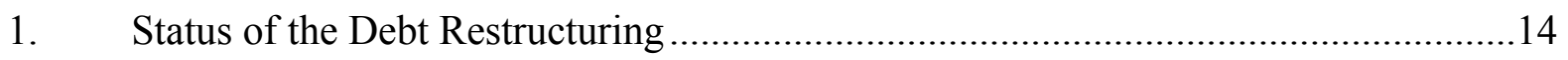

2. Caribbean Development Bank's Support for Debt Restructuring ............................15

Figures

1. External Debt Sustainability: Bound Tests ......................................................... 16

2. Public Debt Sustainability: Bound Tests ................................................................. 17

Tables

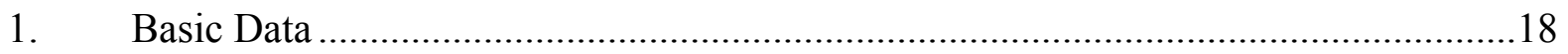

2. Central Government Fiscal Operations, 2007-16 ................................................19

3. Central Government Fiscal Operations, 2007-16....................................................20

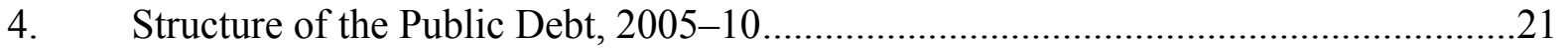

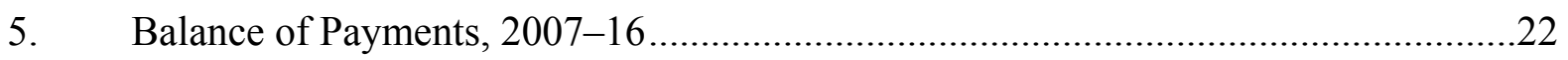

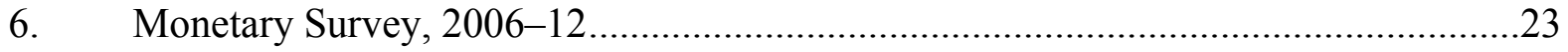

7. Indicators of External and Financial Vulnerability, 2005-10 ...................................24

8. External Financing Requirement and Sources, 2009-16 .......................................25

9. Indicators of Capacity to Repay the Fund, 2012-21 ..........................................26

10. External Debt Sustainability Framework, 2006-16 .............................................27

11. Public Sector Debt Sustainability Framework, 2006-16 ......................................28

Appendix

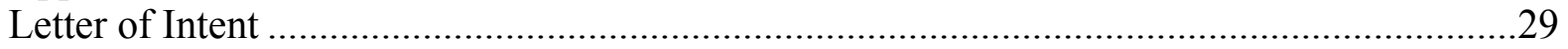

Attachment I. Memorandum of Economic and Financial Policies .............................31

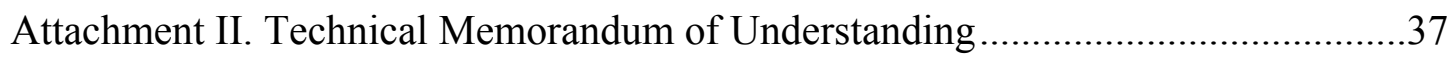

Attachment III. Letter from the Governor ........................................................... 44 


\section{Program Context}

\section{A. Recent Developments}

1. St. Kitts and Nevis' economy is slowly emerging from two consecutive years of contraction.

- Economic activity is estimated to have been flat in 2011, as continued weakness in the construction sector offset the moderate recovery in tourism and manufacturing sectors. Inflation averaged 6.6 percent during the first ten months of the year, reflecting the introduction of the VAT in November 2010, and higher electricity tariffs and international prices of food and fuel, but decelerated to 1.6 percent in November (year-on-year).

- The external current account deficit is estimated to have widened in 2011, with higher energy and food prices more than offsetting the impact of fiscal consolidation and growth in stay-over tourist arrivals. A moderate increase in official capital transfers and FDI, in addition to the Fund disbursement under the SBA, helped finance the current account deficit.

- While standard financial soundness indicators suggest that the financial sector remains healthy, it faces challenges. Available financial sector indicators suggest that the banking system remained well capitalized and liquid, despite a continued challenging economic environment. The Banking Sector Reserve Fund (BSRF), which was established under the SBA, continues to serve as a stabilization mechanism and no request for liquidity support has been made.

St. Kitts and Nevis: Selected Financial Indicators, September 2009-September 2011

\begin{tabular}{|c|c|c|c|c|c|c|c|c|c|}
\hline & Sep-09 & Dec-09 & Mar-10 & Jun-10 & Sep-10 & Dec-10 & Mar-11 & Jun-11 & Sep-11 \\
\hline & \multicolumn{9}{|c|}{ (Annual percentage change) } \\
\hline Broad money & 11.1 & 5.9 & 5.2 & 3.8 & 3.5 & 8.9 & 3.3 & 5.6 & 3.8 \\
\hline Private sector deposits & 9.6 & 5.6 & 5.3 & 3.6 & 3.2 & 7.9 & 2.9 & 5.7 & 3.7 \\
\hline \multirow[t]{2}{*}{ Private sector credit } & 6.2 & 5.5 & 4.0 & 5.8 & 4.9 & 3.5 & 5.8 & 3.8 & 5.6 \\
\hline & \multicolumn{9}{|c|}{ (Percentage change relative to borad money at beginning of period) } \\
\hline Net foreign assets & -1.3 & -8.4 & -0.8 & -5.4 & -5.7 & 1.1 & -1.0 & 7.6 & 11.4 \\
\hline $\begin{array}{l}\text { Net domestic assets } \\
\text { of which: }\end{array}$ & 12.3 & 14.3 & -7.9 & 9.3 & 9.4 & 7.8 & 4.2 & -2.2 & -7.6 \\
\hline Private sector credit & 4.5 & 4.1 & 2.8 & 4.1 & 3.6 & 2.6 & 3.9 & 2.7 & 3.9 \\
\hline \multirow[t]{2}{*}{ Net credit to public sector } & 1.5 & 1.5 & 0.7 & 4.4 & 5.1 & 4.9 & 0.9 & -7.3 & -13.5 \\
\hline & \multicolumn{9}{|c|}{ (Indigenous banks; In percent) } \\
\hline Capital adequacy ratio & $\ldots$ & 49.3 & 48.3 & 48.0 & 51.5 & 43.9 & 46.3 & 48.5 & 41.6 \\
\hline NPLs/Total loans & 4.3 & 4.1 & 5.6 & 5.3 & 5.5 & 5.3 & 5.6 & 5.6 & 5.5 \\
\hline Provisioning/NPLs & 76.5 & 77.7 & 56.6 & 58.3 & 58.5 & 58.1 & 55.8 & 55.5 & 55.2 \\
\hline Net liquid asset/Total deposit & 56.8 & 55.4 & 58.2 & 52.4 & 50.5 & 50.4 & 52.3 & 52.5 & 52.6 \\
\hline
\end{tabular}




\section{B. Program Performance}

The St. Kitts and Nevis authorities steadfastly implemented their home-grown macroeconomic program. All the performance criteria (PCs) for end September 2011 were met. In addition, all, except three, structural benchmarks (SBS) were completed on time. The delayed SBs were completed at the end of December 2011, as prior actions for this review. The authorities have passed the 2012 budget consistent with the program objectives, also a prior action (PA) for the first review.

\section{Despite the adverse global environment, the fiscal targets for}

end-September 2011 were met (MEFP, ๆ 2). The overall fiscal deficit at end-September reached 1.4 percent of annual GDP, above the adjusted program floor and the primary surplus exceeded the program's indicative floor. Despite the slower-than-expected economic growth, total revenue collection was fully in line with projections. At the same time, the authorities constrained expenditure growth consistent with the program. The authorities successfully reduced the stock of central government budget expenditure arrears, and no external arrears were accumulated, except for debt service payments, which are part of the comprehensive debt restructuring. The PC on the stock of central government external shortterm debt was also met.

St. Kitts and Nevis: Quantitative Performance Criteria and Indicative Targets

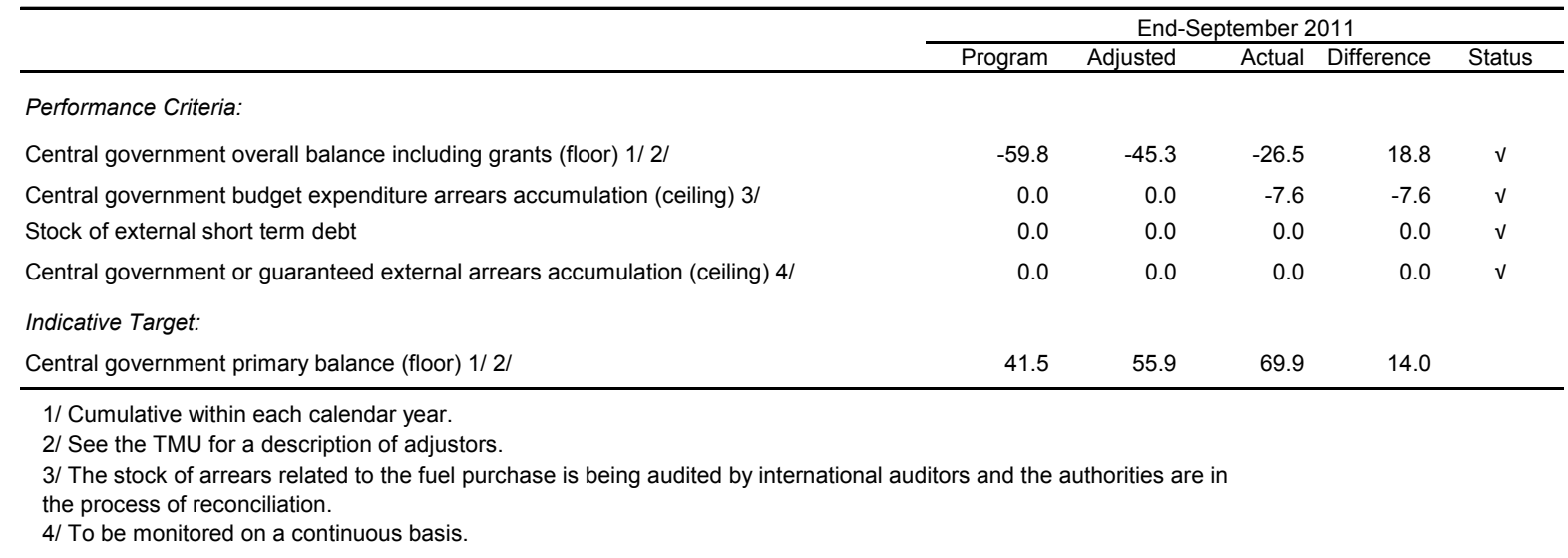

3. The authorities made progress with their structural reform agenda, and all except three structural benchmarks (SBs) were completed by end-September 2011. In line with expectations, substantial progress has been made on the consultative phase of the debt restructuring and an exchange offer is anticipated in the first quarter of 2012. The bill for the corporatization of the Electricity Department (the Electricity Supply Bill) was submitted and passed by Parliament in April 2011, and the corporatization took place on August 1, 2011. The SBs on updating the registry and undertaking a valuation of at least 
600 acres of land fell short by 52 acres, and an update of bank stress tests was delayed. ${ }^{1}$ Completion of these three delayed SBs, as well as parliamentary approval of the 2012 budget consistent with the program objectives were set as prior actions (PAs) for the first review, in light of their criticality ahead of the implementation of comprehensive debt restructuring. Since then, all PAs have been met.

St. Kitts and Nevis: Structural Benchmarks for September 2011

\begin{tabular}{llc}
\hline \multicolumn{1}{c}{ Action } & Target Date \\
\hline Update the registry of at least 600 acres of land & End-September $2011 \quad$ Completed by December-2011 \\
Undertake a valuation of at least 600 acres of land & End-September $2011 \quad$ Completed by December-2011 & End-September 2011 \\
Make substantial progress on the consultative phase of restructuring with creditors & End-September 2011 \\
Submit the bill for the corporatization of the Electricity Department to Parliament & End-September 2011 Completed by December-2011 \\
Update the existing stress tests of financial institutions &
\end{tabular}

\section{Policy Discussions}

The authorities underscored their commitment to the program to ensure that the public debt is sustainable.

\section{Economic growth in $\mathbf{2 0 1 2}$ is expected to be positive, but downside risks remain.} Growth is projected to reach 1.5 percent, supported by FDI-related construction projects and a pick-up in tourism activity. However, the global turmoil continues to highlight increasing downside risks, given the economy's heavy reliance on FDI and tourism. Inflation is expected to revert to its historical average - anchored by the quasi-currency board arrangement with the exchange rate pegged to the U.S. dollar - and projected to reach 2.3 percent in 2012. The external current account is expected to improve in 2012, on account of growth in tourist arrivals. Over the medium term, better global economic conditions and an improved investment climate are projected to result in a recovery in FDI. The overall balance of payments projections suggest that external financing gaps could reach an average of US\$80 million (or about 11 percent of GDP, excluding the potential Fund disbursements) per year during 2012-13, reflecting the maturity profile of the public debt. The comprehensive debt restructuring, including a debt-land swap, as well as support from international financial institutions, including the Fund, are expected to cover the gaps.

\section{A. Maintaining Fiscal Sustainability}

\section{The authorities reiterated their commitment to observing the end-December} 2011 PCs (MEFP, ๆ3), and available evidence suggests that these have likely been met. Overall, revenue performed fully in line with projections. While import related taxes have been underperforming relative to program targets, a more buoyant VAT and better-than-

\footnotetext{
${ }^{1}$ Stress tests were designed with Fund assistance and for the purpose of the debt restructuring include breaking point assessments.
} 
expected revenue performance by the citizenship-by-investment program offset the shortfall. On the expenditure side, expenditure on goods and services (especially fuel purchases) have exceeded the initial projection, while more streamlined capital expenditure compensated for part of the increase. Based on the performance for the first nine months, the overall deficit for the year as a whole is projected to reach EC $\$ 40.5$ million (2.1 percent of GDP), below the initial projection of EC\$59.9 million (3.1 percent of GDP). ${ }^{2}$ The authorities confirmed their commitment to achieving the end-December target, and in line with program objectives, are making efforts to constrain expenditure growth and prioritizing capital expenditure. Also, to this end, the authorities stopped expenditure commitments in early December. On the revenue front, partial data on performance in the fourth quarter suggests that the collection was in line with projections.

\section{The authorities have approved a 2012 budget consistent with the program} objectives (MEFP, $\mid 5$ ), which is a proposed prior action (PA) for the first review. To achieve the revenue target, the authorities intend to pass a new Corporation Tax Act to limit the personal income deduction per person to one corporation or business entity (MEFP, $\mid 6$ ). In addition, the authorities are taking measures to promote tax compliance, including by (i) improving communication with and assistance to the taxpayer population; (ii) refocusing enforcement on the areas of noncompliance that pose the greatest risk to revenue collection; and (iii) intensifying auditing. To this end, they are requesting technical assistance from their development partners and the IMF. On the expenditure front, the authorities continue to be committed to freezing the wage bill and containment in expenditure on goods and services (MEFP, ๆ8).

7. The 2012 projections remain consistent with the program objectives, although the deficit ceiling has been relaxed somewhat. Reflecting the corporatization of the Electricity Department in August 2011, both non-tax revenue and goods and service expenditures show a sharp decline compared to the original program projections with largely neutral impact to

\begin{tabular}{|c|c|c|c|c|c|c|}
\hline & \multicolumn{3}{|c|}{2011} & \multicolumn{3}{|c|}{2012} \\
\hline & & & Excl. Elec. & & & Excl. Elec. \\
\hline & Proj. & Orig. proj. & Dept $1 /$ & Proj. & Orig. proj. & Dept 1/ \\
\hline Total revenue & 596.1 & 611.6 & 576.6 & 524.1 & 636.0 & 559.2 \\
\hline Tax revenue & 409.9 & 412.1 & 412.1 & 420.6 & 443.6 & 443.6 \\
\hline Taxes on income & 85.3 & 87.6 & 87.6 & 83.2 & 92.3 & 92.3 \\
\hline Taxes on property & 8.1 & 9.9 & 9.9 & 10.4 & 11.2 & 11.2 \\
\hline Taxes on domestic goods and consumption & 209.6 & 197.2 & 197.2 & 216.4 & 207.5 & 207.5 \\
\hline Taxes on international trade and transactions & 106.9 & 117.4 & 117.4 & 110.6 & 132.6 & 132.6 \\
\hline Non-tax revenue & 184.7 & 199.5 & 164.4 & 103.5 & 192.4 & 115.6 \\
\hline o/w: Electricity Department & 48.8 & 84.2 & 49.1 & 0.0 & 76.8 & 0.0 \\
\hline Capital revenue & 1.5 & 0.0 & 0.0 & 0.0 & 0.0 & 0.0 \\
\hline Total expenditure and net lending & 704.1 & 723.6 & 685.3 & 663.9 & 726.2 & 646.8 \\
\hline Wages and salaries & 225.5 & 226.0 & 223.7 & 225.1 & 226.0 & 220.6 \\
\hline Goods and services & 195.4 & 185.9 & 149.8 & 108.7 & 182.9 & 108.9 \\
\hline o/w: Electricity Department & 84.6 & 80.7 & 48.8 & 0.0 & 74.0 & 0.0 \\
\hline Interest & 129.8 & 135.6 & 135.6 & 127.7 & 137.0 & 137.0 \\
\hline Transfers & 72.8 & 76.8 & 76.8 & 84.8 & 80.1 & 80.1 \\
\hline Capital expenditure and net lending & 80.5 & 99.4 & 99.4 & 117.7 & 100.1 & 100.1 \\
\hline Grants & 67.5 & 52.1 & 52.1 & 80.1 & 38.9 & 38.9 \\
\hline Overall balance & -40.5 & -59.9 & -56.6 & -59.7 & -51.3 & -48.7 \\
\hline Primary balance & 89.3 & 75.7 & 79.0 & 67.9 & 85.7 & 88.3 \\
\hline
\end{tabular}

\footnotetext{
${ }^{2}$ The national accounts of the ECCU members were rebased in 2011 with a base year of 2006, resulting in a 28 percent increase in St. Kitts and Nevis' nominal GDP for 2009. Based on the previous GDP series, the overall deficit is projected to reach 2.7 percent of GDP compared to the initial projection of 4.0 percent. See Country Report No. 11/270, Box 1, for the key ratios under the rebased and previous GDP.
} 
the overall balances. However, other factors have raised budgetary pressures on both the revenue and the expenditure sides. On the revenue side, import-related taxes are expected to remain weaker, while better-than-projected VAT performance will likely offset part of the shortfall. A more conservative projection for the revenue from the citizenship-byinvestment $^{3}$, given the weaker global economic environment and its potential impact on domestic demand, account for the change in non-tax revenue excluding the impact of the Electricity Department corporatization. On the expenditure front, the government will make external debt service payments on behalf of three public enterprises (equivalent to 0.6 percent of GDP scheduled in 2012) ${ }^{4}$ and it is not clear whether these entities will have the capacity to repay. Hence, the authorities and staff agreed to include them in current transfers to increase transparency. To help offset these adverse factors, capital expenditure is contained by 0.6 percentage point of GDP from previous projection (excluding the start of a grant-financed project in Nevis). As a result, the overall fiscal deficit has been revised upward by 0.5 percentage point from the original program target to 3.0 percent of GDP. Staff considered this revision to be justifiable given the phasing out of the transfers on behalf of the public enterprises, the fact that their debt will be included in the debt restructuring, and the still fragile recovery in 2012. At the same time, to ensure the sustainability of the public enterprises' operations and to minimize associated fiscal risks, the program includes a structural benchmark for end-December 2011 related to the review of the borrowing capacity. The authorities have received information on the financial position of the public enterprises, which will be assessed as soon as possible, but at the latest in the context of the next review. Given the uncertainties about economic prospects and the availability of financing, the authorities have identified contingency measures amounting to 1 percentage point of GDP in case of a shortfall (MEFP, q9). Furthermore, the end-year fiscal target will be revisited in the context of the upcoming reviews, and should be reduced in line with the interest savings from the debt restructuring.

\footnotetext{
${ }^{3}$ Revenue from fees related to large investments in St. Kitts and Nevis, which allows foreigners to obtain citizenship.

${ }^{4}$ The external debt service of these public enterprises is scheduled to be phased out over the next three years, with projected repayment of 0.2 percent and 0.1 percent of GDP in 2013 and 2014.
} 


\section{B. Debt Restructuring}

\section{Fiscal adjustment measures by themselves would not be sufficient to achieve} public debt sustainability. At almost 160 percent of GDP, St. Kitts and Nevis' public debt level is unsustainably high by international standards. The majority of the debt is domestic, and the government has relied heavily on short-term financing. Treasury bills (91-day, 182-day and 365-day) and overdrafts constitute about 30 percent of total domestic debt, which exposes the government to significant rollover risks. Debt sustainability analysis shows that fiscal adjustment under the program will put the debt on a downward trajectory (reaching 130 percent of GDP by 2016), but remain

St. Kitts and Nevis: Public Sector Debt, Dec 2010 (In percent)

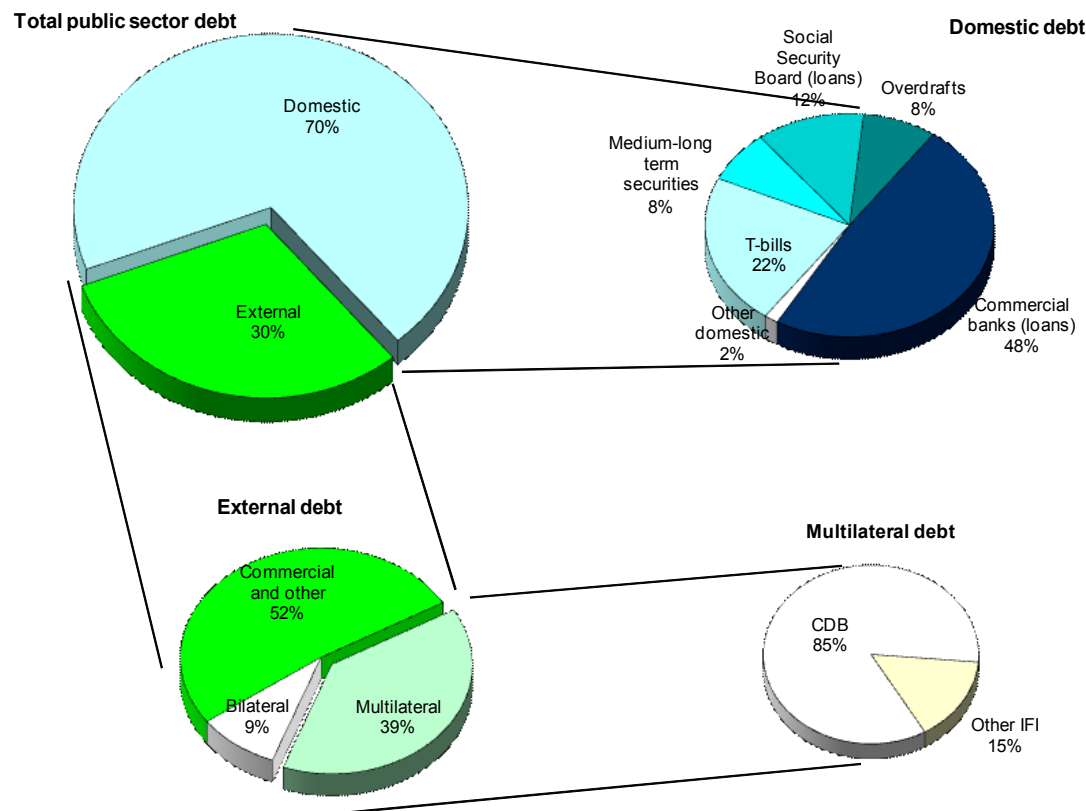
unsustainable and the debt dynamics are extremely susceptible to growth shocks (Tables 10 and 11, and Figures 1 and 2). Therefore, to achieve debt sustainability, a comprehensive and substantive debt restructuring is paramount.

\section{The authorities have announced a comprehensive debt restructuring in} June 2011, and have been in active discussions with creditors. Significant progress has been made on a number of parallel tracks (Box 1). A website has been established to help channel communications with creditors immediately following the announcement. The authorities and their debt advisors presented a set of indicative scenarios to the external commercial creditors in August 2011, and discussions are under way to reach consensus on the central scenario. An exchange offer is anticipated in the first quarter of 2012, and the Caribbean Development Bank (CDB) will provide a partial guarantee for the new instrument, which should improve the prospects for a successful debt exchange (Box 2). The authorities have approached the Paris Club and received financing assurance in July 2011; active negotiations will commence once further progress has been made with commercial creditors. The authorities plan to send a letter to the Paris Club shortly to explain their strategy and sequencing. The authorities have also been in discussions with non-Paris Club bilateral official creditors. 
10. The authorities have approached domestic creditors. The authorities and their advisers are working on a comprehensive offer that will address both secured and unsecured domestic debt. The modalities are still being worked out for the unsecured domestic debt, consistent with the objective of maintaining the health and stability of the domestic financial system. For the secured debt, a debt-land swap is expected to play a key part, and the broad parameters of the Special Purpose Vehicle (SPV) to channel the associated debt/land swap are emerging. The authorities reiterated their commitment to restructure all debt excluding Treasury bills and debt to multilateral creditors.

11. The program is consistent with the Fund's arrears policy. In staff's view, the authorities are in compliance with the Fund's policy on lending into arrears, based on their good faith efforts to engage with their private creditors. In particular, the authorities have initiated collaborative discussions with private creditors and arrears are to be resolved under the debt restructuring process. Staff is of the view that the authorities continue to engage in good faith efforts to reach a collaborative agreement with these creditors. There has been an accumulation of arrears to non-Paris Club bilateral creditors and the authorities have been engaged with these creditors to resolve the arrears and to restructure the debt. Some arrears have been accumulated to Paris Club creditors. For program purposes they are, however, carved out from the continuous PC on the non-accumulation of arrears to external creditors as exemptions, given that a rescheduling agreement is being sought for the debt service concerned.

12. Staff believes that, combined with the fiscal adjustment, the comprehensive debt restructuring will put the public debt on a sustainable trajectory. Preliminary DSA calculations suggest that the debt restructuring (including debt-land swaps) would bring the debt-to-GDP ratio down, in line with the ECCU's target level of 60 percent by 2020.

\section{Reducing Financial Sector Vulnerabilities}

\section{Promoting the health of the financial sector is a key objective of the program.}

Updated stress tests suggested that the banking sector remains healthy and able to withstand significant shocks. Given the importance of preserving the stability of the financial sectorand in line with current practice - the ECCB will continue to undertake regular stress tests, which are now also a quarterly benchmark under the program. In addition, the ECCB is requesting TA, which will further enhance their stress testing capabilities (including multiyear) and allow them to assess the effects of the debt restructuring. The mission emphasized that any participation by domestic banks in a regional consolidation strategy should be consistent with maintaining the stability of the banking system and the objectives of the SBA, while ensuring that risks to the Banking Sector Reserve Fund (BSRF) are minimized. 


\section{Structural Reforms}

14. The authorities are on track to meet the end-December 2011 structural benchmark. With few exceptions, the authorities have received reporting of the financial operations of public enterprises and began to review them.

\section{Structural reform measures in $\mathbf{2 0 1 2}$ will focus on public financial management, the establishment of the SPV, a strengthening of the social safety net, an actuarial review of the Social Security Scheme, and civil service reform.}

- $\quad$ To strengthen public financial management, the authorities are committed to establishing a medium-term expenditure framework (a SB for end-June) and enhancing expenditure control, including through a new Procurement Act (a SB for end-June). With assistance of the Caribbean Development Bank (CDB), the authorities intend to continue enhancing their capacity to implement the Public Sector Investment Program (MEFP, $\llbracket 10)$. Also, the authorities are planning to rationalize the subsidy on liquefied petroleum gas (a SB for end-March) and improve fiscal transparency through regular dissemination of financial data and monitoring of program performance (MEFP, $₫ 12$ and $₫ 13$ ).

- $\quad$ Establishment of a Special Purpose Vehicle to manage and sell land is an important part of the authorities' debt restructuring exercise, and the submission of the draft proposal for its establishment is a SB for end June. In this context, the authorities are committed to the registering and valuating an additional 600 acres of land (SBs for end June) and rationalizing public land sales and rationalizing the number of land development agencies (a SB for end-September).

- $\quad$ Submission of a social safety net reform strategy to Cabinet by end-March is a SB under the program.

- The completion of the regular actuarial review of the Social Security Scheme is a SB for end-September. The Social Security Board is conducting these reviews every three years.

- $\quad$ As part of their fiscal reform strategy, the authorities are committed to approving a plan for civil service reform covering human resource policy, reviewing the organization and structure of the civil service, and addressing wage policy and payroll management (a SB for end-June).

- $\quad$ In line with current practice, the ECCB will update its regular stress tests on a quarterly basis. To highlight its commitment under the program, the ECCB has provided a corresponding letter of support to the government (attachment). Also, in order to improve its capacity to conduct stress testing over multiple years, the ECCB is requesting Fund technical assistance. 


\section{Program Issues}

\section{A. Program Design}

16. The authorities laid out in the attached Letter of Intent (LOI) and Memorandum of Economic and Financial Policies (MEFP) their continued commitments to the program objectives. Some modifications to the program's conditionality are proposed. Also, the definition of domestic debt is clarified by including explicitly bonds issued on the Regional Government Securities Market (RGSM). Arrears accumulated on domestic debt that is subject to the restructuring are excluded from the ceiling on the accumulation of central government budget expenditure arrears.

- $\quad$ Four prior actions for the completion of the first review are proposed: to complete the registry and the evaluation of the remaining 52 acres of land; to update the existing stress tests of banks; and to approve a 2012 budget consistent with the program (MEFP, Table 3).

- $\quad$ Three new structural benchmarks are proposed to be added: to register and evaluate additional 600 acres of land; and for the ECCB to update the regular stress tests on a quarterly basis (MEFP, Table 3).

- $\quad$ Clarification on the bonds issued on the Regional Government Securities Market (RGSM) is proposed: In line with the treatment of such bonds in other Fund-supported programs and to make current understandings explicit, changes to the Technical Memorandum of Understanding (TMU) are proposed to clarify that the RGSM bonds are considered domestic (TMU $₫ 5, \uparrow 13$ ).

- $\quad$ Modification on the PC on budget expenditure arrears is proposed: Given that the authorities are in the process of a comprehensive debt restructuring, including part of the domestic debt, a modification to the TMU is proposed in line with the design of the external arrears PC to exclude arrears accumulated on domestic debt that is subject to the restructuring from the ceiling on the accumulation of central government budget expenditure arrears for PCs from end-March 2012 onwards (TMU \13).

\section{B. Program Risks}

17. Capacity to repay the Fund: With strong program implementation including a comprehensive debt restructuring, St. Kitts and Nevis' capacity to repay the Fund is expected to be adequate (Table 9). Combined with the use of Fund resources from a previous Emergency Natural Disaster Assistance (ENDA), debt service to the Fund will peak in 2016 at 3.6 percent of GDP and 11.5 percent of exports of goods and services, but will significantly fall in the following years. Also, St. Kitts and Nevis has demonstrated to be able to make large debt service payments - 14.7 percent of GDP on average over the past 5 years. 
Access under the program has been heavily frontloaded (249 percent of quota) in large part to establish the Banking Sector Reserve Fund at the time of program approval (120 percent of quota), but the debt restructuring will help put debt firmly on a downward trajectory. The staff is of the view that the authorities' commitment to the Fund-supported program will deepen St. Kitts and Nevis' ability to access markets and strengthen public finances allowing the government to discharge its obligations in a timely manner.

18. Other risks include:

- Growth: recent data provide greater confidence that the economy is turning toward a modest recovery, but spillovers from possible economic distress emanating from Europe and North America are key risks to this outlook given St. Kitts and Nevis openness and dependence on tourism from these markets.

- Debt restructuring: continued uncertainty over the duration and outcome of the negotiations could lead to the postponement of critical investment decisions and reduce the likelihood that the objectives of the restructuring are achieved. The modalities of the debt restructuring also need to be consistent with a healthy financial system, including the associated debt land swap.

- Expenditure control: in spite of the authorities' commitment to implementing their home-grown program, a natural disaster could derail fiscal adjustment.

- Capacity constraints: these could complicate structural reforms.

The program design addresses these risks through identification of contingency measures amounting to 1 percentage point of GDP, a ceiling on budgetary expenditure and external arrears, a realistic timetable for structural reforms, and continued technical assistance.

\section{StafF ApPRAisal}

\section{The St. Kitts and Nevis authorities have initiated a track record of resolute} policy implementation. In the face of adverse global developments, the authorities have persevered with the introduction of politically difficult but critically important fiscal measures and the initiation of a comprehensive debt restructuring, which have begun to achieve positive results.

20. Looking ahead, maintaining the momentum for fiscal reforms will be essential to achieving fiscal and debt sustainability. Given tax compliance risks and greater demands for taxpayer support, the authorities' focus on promoting tax compliance and helping taxpayers to cope with the crisis is a welcome step to preserve the revenue base to avoid further expenditure cuts to meet the fiscal targets under the program. In this context, staff supports the authorities request for technical assistance in strengthening tax administration. 
Staff also welcomes the contingency revenue and expenditure measures identified by the authorities in case of a shortfall.

21. While the authorities' progress on the debt restructuring is welcome, early implementation is critical. Debt restructuring, including the debt-land swap, remains an important plank of the program as it will complement the ongoing fiscal effort and ensure burden sharing by all. Mindful that St. Kitts and Nevis' prospects for achieving these outcomes are dependent on the success of the broader efforts to maintain financial stability across the Eastern Caribbean Currency Union, staff is confident that the authorities will be in a position to launch an exchange offer in the near future that will deliver a substantial debt relief sufficient to fill the remaining financing gaps, while maintaining the stability of the domestic financial system.

22. On the basis of the authorities' resolute track record of policy implementation, staff supports their request for the completion of the first review under the SBA the financing assurances review, and the modification of one performance criterion. Staff judges that the program will be successfully implemented, notwithstanding the unavailability of information necessary to assess observance of the end-December 2011 PCs and there is no clear evidence that the performance criteria related to end-December 2011 will not be met, and accordingly staff also supports the request for waivers of applicability for all end-December 2011 performance criteria. 


\section{Box 1. Status of the Debt Restructuring}

The authorities and their advisers continue to work on the debt restructuring. Significant progress has been made on a number of parallel tracks, and staff are confident that the objectives of the program will be met:

\section{External commercial creditors and bond holders}

- $\quad$ Active and constructive discussions have been held - both at a bilateral and multilateral level—with all significant creditors.

- An indicative set of scenarios - implying a significant haircut - has been shared with external commercial creditors and bondholders and discussions suggest that a consensus is emerging. The advisers anticipate launching a formal exchange offer early in 2012.

\section{Official sector creditors}

- $\quad$ The authorities have approached the Paris Club and received financing assurance in July. Active negotiations will commence once further progress has been made with commercial creditors. Discussions have also been initiated with other non-Paris Club bilateral official creditors.

- $\quad$ On December 20 the CDB approved a number of measures to support the debt restructuring and economic program of St. Kitts and Nevis (see Box 2).

\section{Domestic creditors}

- $\quad$ The authorities and their advisers are working on a comprehensive offer that will address both secured and unsecured domestic debt. The objective is to preserve the stability of the domestic financial system, while securing sufficient debt relief. A debt-land swap is expected to play a key role in terms of the secured domestic debt restructuring, and the parameters of the associated SPV are being outlined. 


\section{Box 2. Caribbean Development Bank's Support for Debt Restructuring}

CDB's efforts to support the debt restructuring process and enhance growth include the following measures:

A New Guarantee Facility: The authorities believed that the CDB would have a far greater impact on the debt restructuring if its assistance were channeled in the form of a guarantee on the new debt instrument rather than other forms of financial support. The CDB guarantee will enhance the authorities' ability to achieve a high participation rate in the restructuring as the creditors would assign a value to a guarantee from a strong multilateral institution, and therefore a greater incentive to exchange their existing claims even if it meant significant concessions in the process. As a result of the authorities' request, the CDB Board approved a US\$12 million guarantee on the new debt instruments in December 2011.

Restructuring the Existing Guarantee Facility: The CDB provided a guarantee of US\$8.3 million on a bond issued by the government in 2008. One-half of this guarantee was called in September, giving rise to a liability of US\$4.1 million, payable upon demand. The authorities requested a restructuring of the repayment of the receivable and CDB's Board agreed to restructure it by converting it into a loan from its concessional resources. In order to provide for the possibility that the guaranteed bond is not restructured before the next debt service payment becomes due, the Board also approved a loan of US $\$ 8.3$ million, which is repayable over 25 years, inclusive of a five-year grace period at a rate of 2.5 percent. These terms of the loan are those that would normally be obtained for a Group 3 country, and while St. Kitts and Nevis is classified as a Group 2 country, the Board agreed to provide the loan on more favorable terms given the macroeconomic context.

Softer Financing for Projects: The Board agreed to convert the outstanding "hard" component on four existing loans into soft terms. The outstanding amount on the loans is US\$8.8 million, which will be converted into loans with a repayment period of 25 years, inclusive of a five-year grace period. 
Figure 1. St. Kitts and Nevis: External Debt Sustainability: Bound Tests 1/ (External debt in percent of GDP)
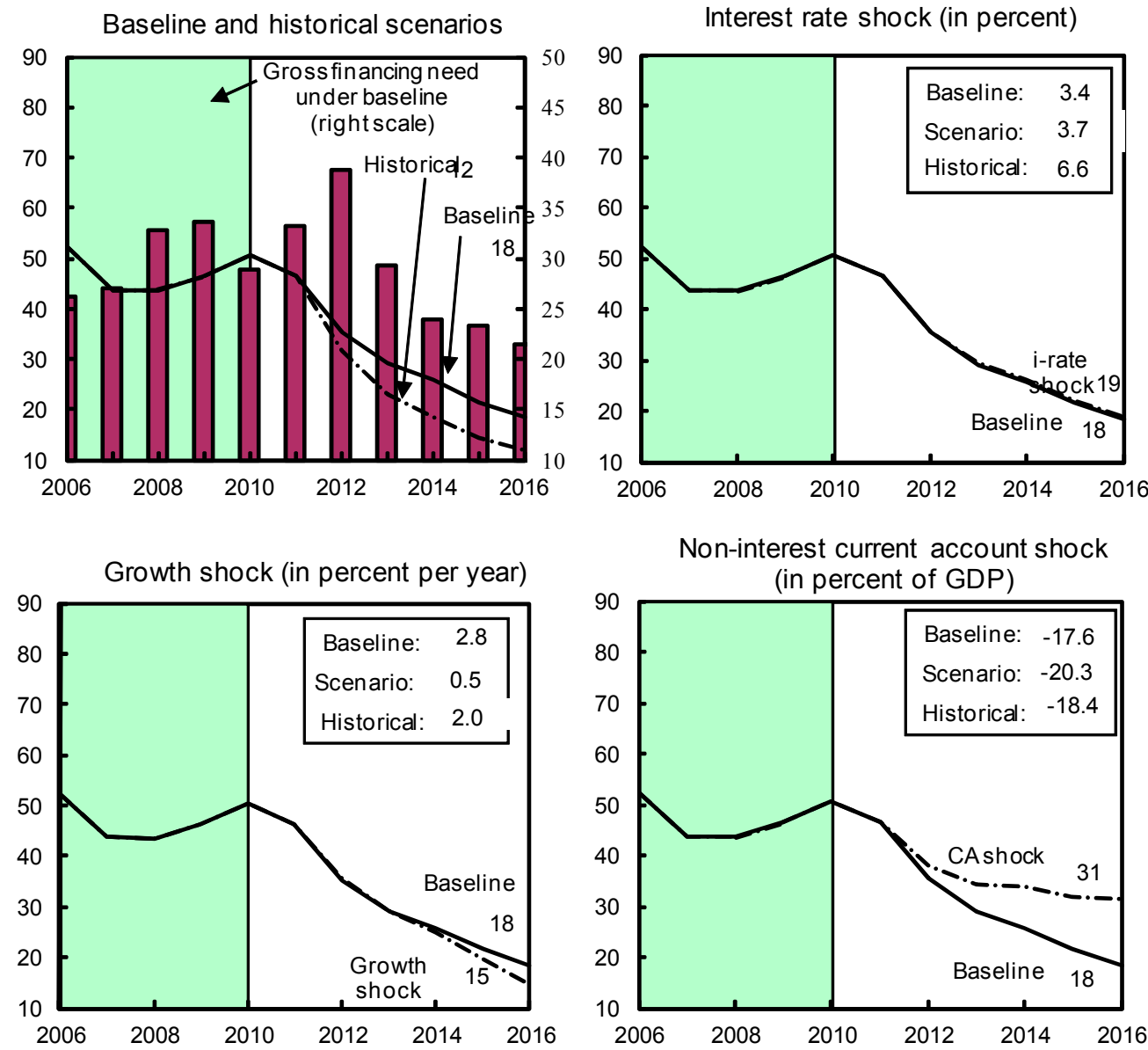

Non-interest current account shock (in percent of GDP)

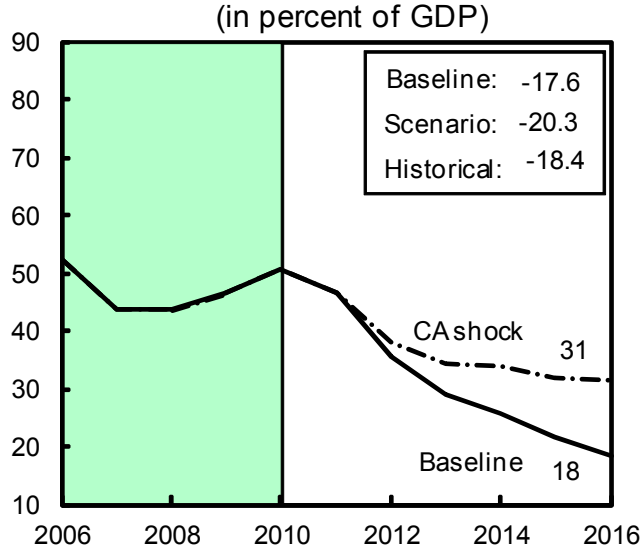

Combined shock 2/
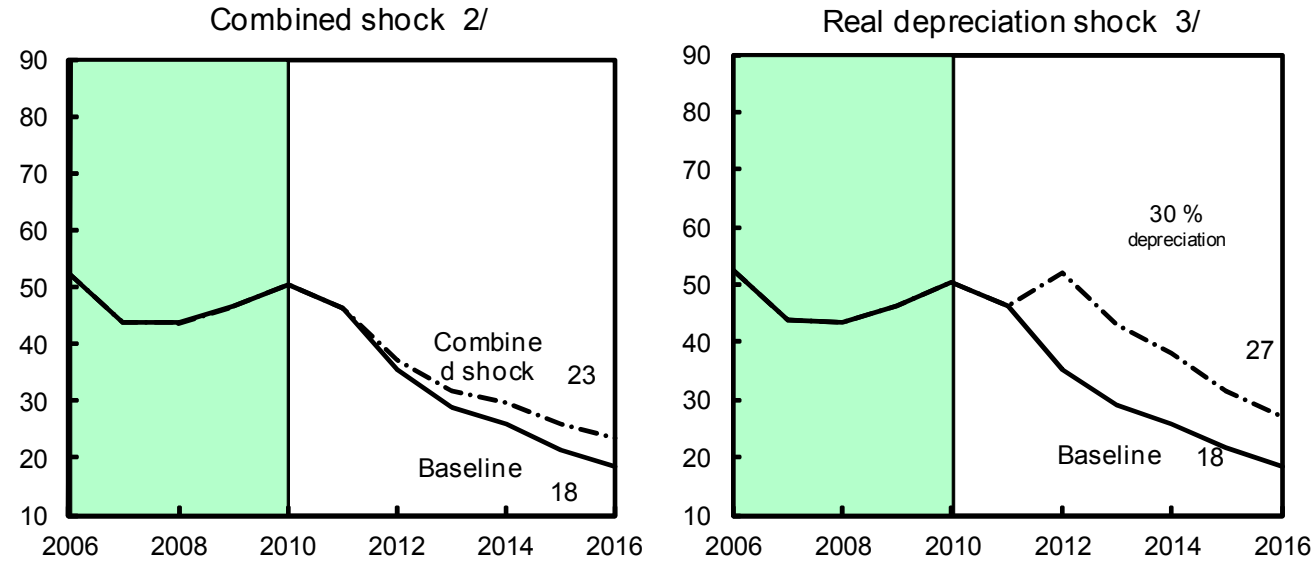

Sources: International Monetary Fund, Country desk data, and staff estimates. $1 /$ Shaded areas represent actual data. Individual shocks are permanent one-half standard deviation shocks. Figures in the boxes representaverage projections for the respective variables in the baseline and scenario being presented. Ten-year historical average for the variable is also shown. 2/Permanent $1 / 4$ standard deviation shocks applied to real interest rate, growth rate, and current account balance.

3/ One-time real depreciation of 30 percent occurs in 2010. 
Figure 2. St. Kitts and Nevis: Public Debt Sustainability: Bound Tests 1/2/ (Public debt in percent of GDP)
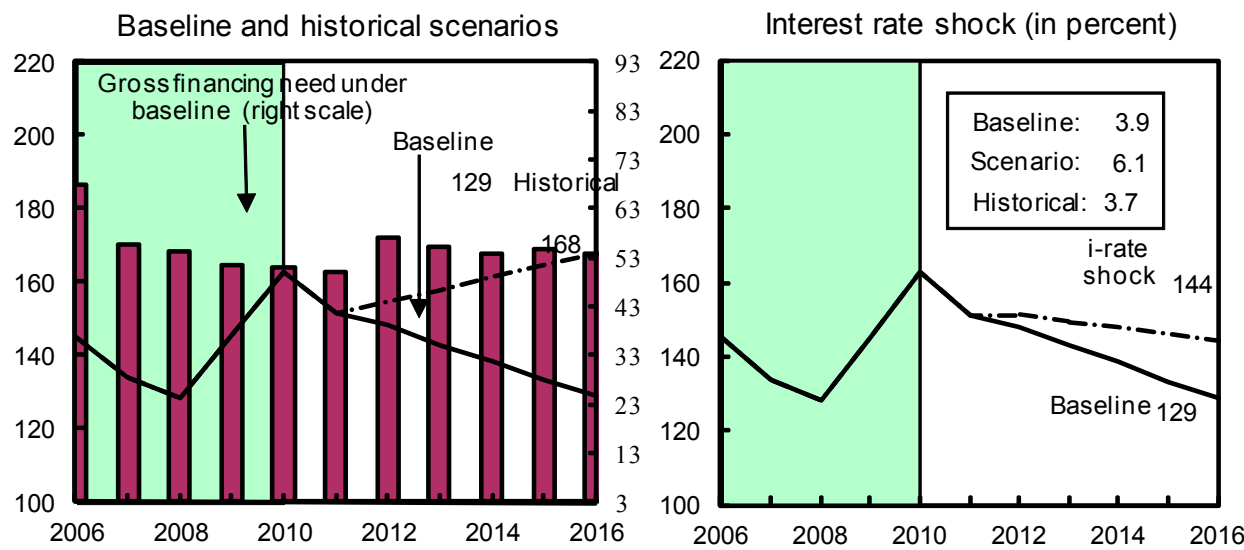

Growth shock

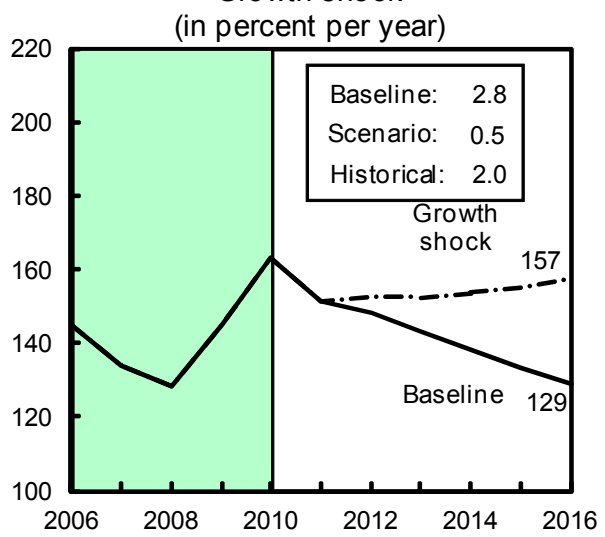

Primary balance shock (in percent of GDP) and no policy change scenario (constant primary
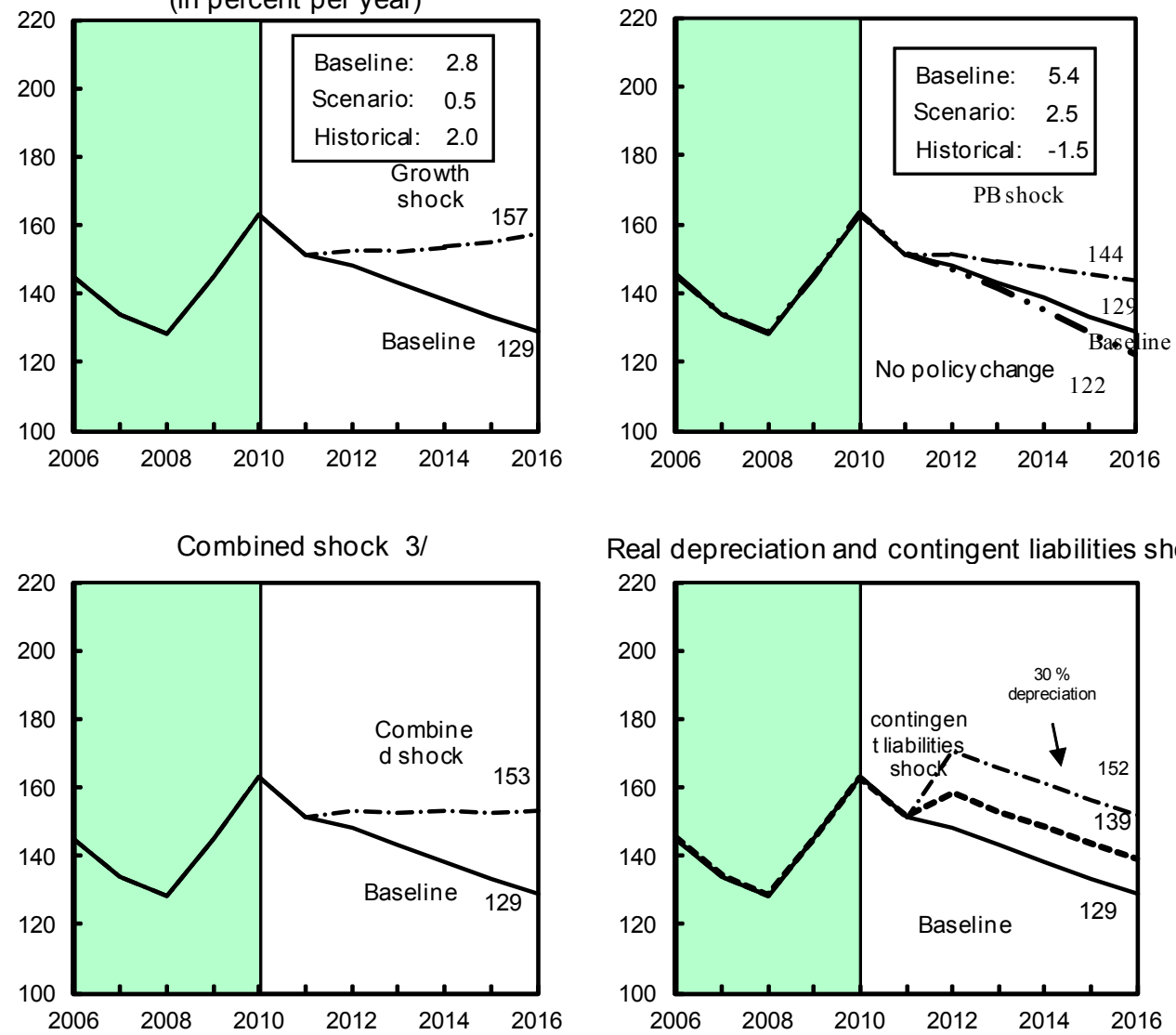

Real depreciation and contingent liabilities shocks 4/

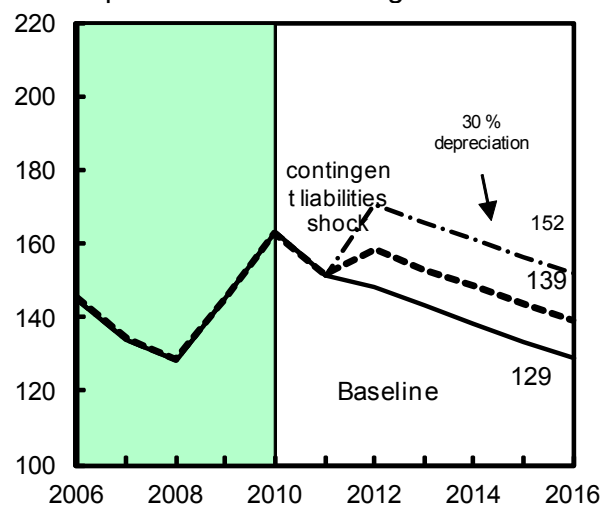

Sources: Intemational Monetary Fund, country desk data, and staff estimates.

$1 /$ Shaded areas rep resent actual data. In dividual shocks are permanent one-half standard deviation shocks. Figures in the boxes represent average projections for the respective variables in the baseline and scenario being presented. Ten-year historical average for the variable is also shown.

$2 /$ For historical scenarios, the historical averages are calculated over the ten-year period, and the information is used to project debt dynamics five years ahead.

$3 /$ Permanent $1 / 4$ standard deviation shocks ap plied to real interest rate, growth rate, and primary balance. 4/ One-time real depreciation of 30 percent and 10 percent of GDP shock to contingent liabilities occur in 2010 , with real depreciation defined as nominal depreciation (measured by percentage fall in dollar value of local currency) minus domestic inflation (based on GDP d eflator). 
Table 1. St. Kitts and Nevis: Basic Data

Area (sq. km)

Population

Total (thousands, 2001)

Rate of growth (percent per year, 2001)

Density (per sq. km., 2001)

Net migration rate (per thousand, 2002)

Population characteristics (2008)

Infant mortality (per thousand live births)

Under 5 mortality rate (per thousand)
I. Social and Demographic Indicators

269.4

Adult literacy rate (percent, 2009)

97.8

46.1
0.02
171.2

0.02
171.2
-9.8

Health and nutrition

Calorie intake (per capita a day, 1996) 2,639

Population per physician (thousand, 2000)

Access to safe water (percent, 2008)

Gross domestic product (2010)

(millions of U.S. dollars)

1,818
11,977

II. Economic and Financial Indicators, 2005-12

\begin{tabular}{|c|c|c|c|c|c|c|c|c|}
\hline & 2005 & 2006 & 2007 & 2008 & 2009 & $\begin{array}{l}\text { Prel. } \\
2010 \\
\end{array}$ & $\begin{array}{l}\text { Proj. } \\
2011 \\
\end{array}$ & $\begin{array}{l}\text { Proj. } \\
2012 \\
\end{array}$ \\
\hline \multicolumn{9}{|c|}{ (Annual percentage change; unless otherwise specified) } \\
\hline \multicolumn{9}{|l|}{ National income and prices } \\
\hline Real GDP (factor cost) & 9.2 & 3.5 & 5.0 & 4.0 & -5.6 & -2.7 & 0.0 & 1.5 \\
\hline Consumer prices, end-of-period & 6.0 & 7.9 & 2.9 & 6.5 & 1.2 & 5.0 & 1.4 & 2.2 \\
\hline Consumer prices, period average & 3.4 & 8.5 & 4.5 & 5.3 & 2.1 & 0.7 & 6.3 & 2.3 \\
\hline Real effective exchange rate (end-of-period) 1/ & 2.8 & 2.2 & -5.5 & 12.8 & -3.8 & -5.6 & $\cdots$ & $\ldots$ \\
\hline \multicolumn{9}{|l|}{ Banking system } \\
\hline Net foreign assets $1 /$ & 7.8 & 6.4 & 6.9 & 11.6 & -8.4 & 1.1 & 4.7 & 1.5 \\
\hline \multicolumn{9}{|l|}{ Of which } \\
\hline Credit to private sector $1 / 2 /$ & 5.8 & 8.4 & 8.6 & 4.3 & 4.1 & 2.6 & 2.0 & 2.6 \\
\hline Broad money $2 /$ & 6.6 & 13.6 & 11.9 & 1.6 & 5.9 & 8.9 & 6.0 & 4.1 \\
\hline \multicolumn{9}{|l|}{ Of which } \\
\hline Money & 2.3 & 14.5 & 12.2 & 11.4 & -3.1 & 43.1 & 6.0 & 4.1 \\
\hline Quasi-money & 7.3 & 13.5 & 11.9 & 0.0 & 7.5 & 3.3 & 6.0 & 4.1 \\
\hline \multicolumn{9}{|c|}{ (In percent of GDP) } \\
\hline \multicolumn{9}{|l|}{ Public sector $3 /$} \\
\hline Primary balance & 3.3 & 3.7 & 2.7 & 2.6 & 3.7 & -0.8 & 4.6 & 3.4 \\
\hline Overall balance & -3.3 & -3.9 & -3.5 & -3.9 & -2.9 & -7.8 & -2.1 & -3.0 \\
\hline Current revenue & 30.0 & 28.5 & 27.8 & 27.2 & 29.0 & 28.2 & 30.9 & 26.1 \\
\hline Grants & 2.2 & 2.1 & 1.5 & 1.4 & 3.6 & 2.8 & 3.5 & 4.0 \\
\hline Current expenditure & 30.1 & 28.4 & 26.7 & 27.3 & 30.4 & 31.7 & 32.4 & 27.2 \\
\hline Capital expenditure and net lending & 5.4 & 6.2 & 6.1 & 5.3 & 5.1 & 7.1 & 4.2 & 5.9 \\
\hline Foreign financing & -3.3 & -0.3 & -1.2 & 3.5 & 0.2 & 1.3 & 0.7 & -4.1 \\
\hline Domestic financing & 14.5 & 4.7 & 2.8 & -4.4 & 2.1 & 6.2 & -4.4 & 0.4 \\
\hline Sale of assets & 0.3 & 0.4 & 2.0 & 3.1 & 1.7 & 0.7 & 3.2 & 0.2 \\
\hline Change in arrears 4/ & & & & 0.7 & 1.1 & 2.5 & 2.5 & -7.5 \\
\hline Statistical discrepancy & -8.1 & -0.9 & 0.0 & 1.0 & -2.2 & -2.9 & - & - \\
\hline Financing gap $5 /$ & & & & & & & 0.0 & 14.0 \\
\hline Total public debt (end-of-period) & 159.9 & 145.3 & 134.0 & 128.4 & 145.1 & 163.0 & 151.3 & 148.2 \\
\hline \multicolumn{9}{|l|}{ Of which } \\
\hline Central government 6/ & 101.0 & 108.8 & 101.5 & 97.9 & 111.5 & 127.4 & 120.0 & 118.1 \\
\hline Public enterprises $6 /$ & 58.9 & 36.5 & 32.5 & 30.5 & 33.5 & 35.7 & 31.3 & 30.1 \\
\hline Public debt service (percent of total revenue and grants) $7 /$ & 32.5 & 34.3 & 30.1 & 28.4 & 25.2 & 25.9 & 29.3 & 60.3 \\
\hline \multicolumn{9}{|l|}{ External sector } \\
\hline External current account balance & -14.9 & -15.8 & -18.1 & -25.6 & -26.0 & -21.4 & -22.5 & -21.4 \\
\hline Trade balance & -22.7 & -25.6 & -26.4 & -29.3 & -28.6 & -24.4 & -27.4 & -26.9 \\
\hline Services, net & 12.7 & 12.1 & 10.3 & 5.5 & 4.7 & 4.5 & 5.2 & 5.7 \\
\hline \multicolumn{9}{|l|}{ Of which } \\
\hline Tourism receipts & 22.6 & 20.9 & 18.1 & 14.9 & 12.1 & 12.2 & 12.7 & 13.2 \\
\hline Transfers, net & 4.5 & 5.1 & 4.2 & 4.5 & 4.2 & 4.6 & 4.7 & 4.7 \\
\hline Net capital inflow $8 /$ & 13.7 & 18.5 & 19.1 & 26.8 & 26.7 & 23.7 & 20.6 & 14.2 \\
\hline FDI (net) & 17.3 & 17.5 & 19.5 & 24.0 & 19.0 & 16.1 & 16.4 & 16.7 \\
\hline External financing gap $5 /$ & & & & & & & 0.0 & 14.5 \\
\hline External public debt (end-of-period) & 62.5 & 52.3 & 43.7 & 43.6 & 46.5 & 50.5 & 46.5 & 35.4 \\
\hline \multicolumn{9}{|c|}{ (In percent of exports of goods and nonfactor services) } \\
\hline External public debt service & 22.0 & 22.7 & 21.0 & 18.8 & 21.8 & 19.6 & 33.2 & 24.3 \\
\hline External public debt (end-of-period) & 147.8 & 139.7 & 130.6 & 140.3 & 172.4 & 183.0 & 163.9 & 122.3 \\
\hline \multicolumn{9}{|l|}{ Memorandum items } \\
\hline Net imputed reserves, end-of-period & & & & & & & & \\
\hline (in millions of U.S. dollars) & 71.5 & 88.6 & 95.6 & 110.2 & 122.9 & 155.7 & 171.1 & 169.3 \\
\hline (in percent of broad money) & 15.1 & 16.5 & 15.9 & 18.0 & 19.0 & 22.1 & 22.9 & 21.8 \\
\hline Holding of SDRs, millions of U.S. dollars & 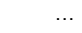 & & 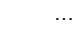 & & 13.3 & 12.8 & 12.8 & 12.8 \\
\hline Nominal GDP at market prices (in millions of EC dollars) & $1,448.3$ & $1,699.7$ & $1,861.6$ & $1,998.3$ & $1,859.4$ & $1,817.6$ & $1,927.2$ & $2,005.5$ \\
\hline
\end{tabular}

Sources: St. Kitts and Nevis authorities; ECCB; UNDP; World Bank; and Fund staff estimates and projections.

$1 /$ In relation to broad money at the beginning of the period.

2/ Data from 2009 includes non-bank financial institutions and subsidiaries and affiliates as parts of private sector to reflect the changes in definition

in Jan 2009.

3/ Central government unless otherwise noted.

4/ The stock of arrears related to the fuel purchase is being auditied by itnernational auditors and the authorities are in the

process of reconciliation.

$5 /$ The financing gap to be closed through debt restructuring and IMF financing

6/ St. Kitts Sugar Manufacturing Corporation (SSMC) debt included in central government debt since 2006 .

$7 /$ Includes interest and external amortization of central government.

$8 /$ Includes errors and omissions. 
Table 2. St. Kitts and Nevis: Central Government Fiscal Operations, 2007-16 1/

(In millions of Eastern Caribbean dollars)

\begin{tabular}{|c|c|c|c|c|c|c|c|c|c|c|c|}
\hline & \multirow[b]{2}{*}{2007} & \multirow[b]{2}{*}{2008} & \multirow[b]{2}{*}{2009} & \multicolumn{2}{|c|}{ Program } & \multicolumn{6}{|c|}{ Proj. } \\
\hline & & & & 2010 & 2011 & 2011 & 2012 & 2013 & 2014 & 2015 & 2016 \\
\hline Total revenue & 517.3 & 544.4 & 539.4 & 513.5 & 611.6 & 596.1 & 524.1 & 569.0 & 600.5 & 636.6 & 674.9 \\
\hline Current revenue & 517.3 & 544.4 & 539.4 & 513.5 & 611.6 & 594.6 & 524.1 & 569.0 & 600.5 & 636.6 & 674.9 \\
\hline Tax revenue & 400.4 & 422.0 & 396.1 & 342.4 & 412.1 & 409.9 & 420.6 & 451.6 & 476.8 & 505.8 & 536.5 \\
\hline Taxes on income & 116.0 & 135.7 & 148.7 & 92.6 & 87.6 & 85.3 & 83.2 & 91.4 & 96.5 & 102.4 & 108.6 \\
\hline Taxes on property & 7.4 & 6.6 & 8.8 & 9.4 & 9.9 & 8.1 & 10.4 & 11.6 & 12.3 & 13.0 & 13.8 \\
\hline Taxes on domestic goods and consumption 2 & 84.1 & 83.9 & 69.6 & 84.2 & 197.2 & 209.6 & 216.4 & 232.3 & 245.3 & 260.2 & 276.0 \\
\hline Taxes on international trade and transactions & 192.9 & 195.9 & 169.0 & 156.3 & 117.4 & 106.9 & 110.6 & 116.2 & 122.7 & 130.1 & 138.0 \\
\hline Nontax revenue $3 /$ & 116.8 & 122.5 & 143.3 & 171.0 & 199.5 & 184.7 & 103.5 & 117.5 & 123.7 & 130.8 & 138.4 \\
\hline Capital revenue & 0.0 & 0.0 & 0.0 & 0.0 & & 1.5 & 0.0 & 0.0 & 0.0 & 0.0 & 0.0 \\
\hline Total expenditure and net lending & 611.6 & 650.4 & 661.1 & 706.1 & 723.6 & 704.1 & 663.9 & 661.7 & 683.5 & 718.7 & 768.9 \\
\hline Current expenditure & 497.8 & 545.3 & 565.6 & 576.3 & 624.3 & 623.6 & 546.3 & 554.6 & 570.5 & 598.9 & 641.9 \\
\hline Wages and salaries & 185.8 & 204.5 & 233.4 & 224.0 & 226.0 & 225.5 & 225.1 & 225.1 & 230.7 & 241.2 & 255.7 \\
\hline Goods and services $3 /$ & 141.5 & 151.8 & 150.1 & 169.1 & 185.9 & 195.4 & 108.7 & 109.4 & 112.5 & 119.3 & 126.6 \\
\hline Interest & 116.3 & 128.7 & 123.2 & 127.0 & 135.6 & 129.8 & 127.7 & 143.0 & 149.2 & 157.2 & 173.4 \\
\hline Domestic & 77.3 & 86.8 & 81.6 & 86.7 & 100.9 & 103.4 & 103.3 & 123.0 & 133.5 & 142.1 & 158.4 \\
\hline Foreign & 39.0 & 41.9 & 41.6 & 40.3 & 34.7 & 26.4 & 24.4 & 20.0 & 15.7 & 15.0 & 15.0 \\
\hline Transfers & 54.1 & 60.3 & 58.9 & 56.2 & 76.8 & 72.8 & 84.8 & 77.1 & 78.1 & 81.2 & 86.1 \\
\hline Net lending & 13.1 & 15.4 & 7.6 & 5.8 & 1.0 & 1.0 & 1.0 & 1.0 & 1.0 & 1.0 & 1.0 \\
\hline Capital expenditure & 100.7 & 89.7 & 87.9 & 124.0 & 98.4 & 79.5 & 116.7 & 106.1 & 112.0 & 118.8 & 126.1 \\
\hline Current balance & 19.5 & -0.9 & -26.2 & -62.8 & -12.6 & -29.0 & -22.2 & 14.4 & 30.0 & 37.7 & 33.0 \\
\hline Overall balance (before grants) & -94.3 & -106.0 & -121.7 & -192.6 & -112.0 & -108.0 & -139.8 & -92.7 & -83.0 & -82.1 & -94.0 \\
\hline Grants & 28.4 & 28.3 & 67.5 & 50.7 & 52.1 & 67.5 & 80.1 & 48.1 & 6.0 & 6.0 & 6.0 \\
\hline Overall balance (after grants) & -65.9 & -77.7 & -54.2 & -141.9 & -59.9 & -40.5 & -59.7 & -44.6 & -77.0 & -76.1 & -88.0 \\
\hline Primary balance & 50.5 & 51.0 & 69.0 & -14.9 & 75.7 & 89.3 & 67.9 & 98.4 & 72.1 & 81.0 & 85.4 \\
\hline Financing & 66.2 & 58.7 & 95.0 & 195.1 & -110.4 & 40.5 & -220.5 & -90.8 & -18.9 & -34.7 & -87.0 \\
\hline Net foreign financing & -23.0 & 70.3 & 2.9 & 23.0 & -57.4 & 14.3 & -82.8 & -103.6 & -42.5 & -76.7 & -67.5 \\
\hline Disbursements & 24.9 & 104.3 & 32.2 & 41.9 & 6.9 & 112.7 & 4.0 & 2.5 & 1.4 & 0.3 & 0.0 \\
\hline Amortization 4/ & 47.9 & 33.9 & 29.2 & 18.9 & 64.3 & 98.4 & 86.8 & 106.1 & 43.9 & 77.0 & 67.5 \\
\hline Net domestic financing & 52.8 & -88.5 & 39.7 & 113.1 & -56.9 & -84.7 & 8.3 & 8.7 & 14.9 & 32.8 & -29.3 \\
\hline Banking system & 26.6 & -133.9 & 17.1 & 101.7 & 0.0 & -99.3 & 0.0 & 0.0 & 5.8 & 23.1 & -39.6 \\
\hline o/w: Principal repayments of SSMC debt & 0.0 & 0.0 & 0.0 & 0.0 & 0.0 & -56.9 & 0.0 & 0.0 & 0.0 & 0.0 & -56.9 \\
\hline Nonbanks and other & 26.2 & 45.4 & 22.6 & 11.4 & -56.9 & 14.6 & 8.3 & 8.7 & 9.2 & 9.7 & 10.3 \\
\hline Sale/purchase of assets & 36.4 & 62.3 & 31.4 & 12.8 & 3.9 & 62.3 & 3.9 & 4.1 & 8.7 & 9.2 & 9.8 \\
\hline Change in arrears & & 14.6 & 21.0 & 46.2 & $\ldots$ & 48.6 & -149.9 & 0.0 & 0.0 & 0.0 & 0.0 \\
\hline o/w: unpaid fuel expenses $5 /$ & & 14.6 & 21.0 & 46.2 & . & 31.6 & -149.9 & 0.0 & 0.0 & 0.0 & 0.0 \\
\hline Statistical discrepancy & -0.3 & 19.0 & -40.8 & -53.2 & 0.0 & 0.0 & 0.0 & 0.0 & 0.0 & 0.0 & 0.0 \\
\hline Financing gap & 0.0 & 0.0 & 0.0 & 0.0 & 170.4 & 0.0 & 280.3 & 135.4 & 95.9 & 110.8 & 175.1 \\
\hline \multicolumn{12}{|l|}{ Memorandum items: } \\
\hline GDP (market prices) & 1,862 & 1,998 & 1,859 & 1,818 & 1,918 & 1,927 & 2,006 & 2,107 & 2,224 & 2,360 & 2,503 \\
\hline Stock of unpaid fuel expenses $5 /$ & & 15 & 36 & 118 & 74 & 150 & 0 & 0 & 0 & 0 & 0 \\
\hline $\begin{array}{l}\text { Public sector debt (end of period) } 5 / \\
\text { Of which }\end{array}$ & 2,494 & 2,565 & 2,698 & 2,963 & 2,867 & 2,916 & 2,972 & 3,012 & 3,081 & 3,147 & 3,226 \\
\hline Central government 6/ & 1,889 & 1,956 & 2,074 & 2,315 & 2,263 & 2,312 & 2,368 & 2,408 & 2,476 & 2,543 & 2,622 \\
\hline Domestic & 1,350 & 1,351 & 1,455 & 1,641 & 1,625 & 1,524 & 1,762 & 1,881 & 1,971 & 2,089 & 2,202 \\
\hline External $5 /$ & 539 & 605 & 619 & 674 & 638 & 788 & 606 & 527 & 506 & 454 & 419 \\
\hline
\end{tabular}

Sources: St. Kitts and Nevis authorities; and Fund staff estimates and projections.

1/ Combined accounts of the Federal Government of St. Kitts and Nevis and the Nevis Island Administration.

2/ The sharp drop in international taxes and concurrent rise in taxes on domestic goods and services reflect the introduction of VAT in November 2010.

3/ The sharp drop in 2012 reflects the corporatization of the Electricity Department in August 2011

4/ Includes amortization for three public enterprises equivalent to EC\$19.9million in 2011.

5/ Estimates for 2008 and 2009. The authorities have hired international auditors to audit and reconcile the stock of arrears.

$6 /$ Reflects the updated series for the stock of budgetary arrears from 2010. 
Table 3. St. Kitts and Nevis: Central Government Fiscal Operations, 2007-16 1/

(In percent of GDP)

\begin{tabular}{|c|c|c|c|c|c|c|c|c|c|c|c|}
\hline & \multirow[b]{2}{*}{2007} & \multirow[b]{2}{*}{2008} & \multirow[b]{2}{*}{2009} & \multirow{2}{*}{\multicolumn{2}{|c|}{$\begin{array}{r}\text { Program } \\
2011\end{array}$}} & \multicolumn{6}{|c|}{ Proj. } \\
\hline & & & & & & 2011 & 2012 & 2013 & 2014 & 2015 & 2016 \\
\hline Total revenue & 27.8 & 27.2 & 29.0 & 28.2 & 31.9 & 30.9 & 26.1 & 27.0 & 27.0 & 27.0 & 27.0 \\
\hline Current revenue & 27.8 & 27.2 & 29.0 & 28.2 & 31.9 & 30.9 & 26.1 & 27.0 & 27.0 & 27.0 & 27.0 \\
\hline Tax revenue & 21.5 & 21.1 & 21.3 & 18.8 & 21.5 & 21.3 & 21.0 & 21.4 & 21.4 & 21.4 & 21.4 \\
\hline Taxes on income & 6.2 & 6.8 & 8.0 & 5.1 & 4.6 & 4.4 & 4.1 & 4.3 & 4.3 & 4.3 & 4.3 \\
\hline Taxes on property & 0.4 & 0.3 & 0.5 & 0.5 & 0.5 & 0.4 & 0.5 & 0.6 & 0.6 & 0.6 & 0.6 \\
\hline Taxes on domestic goods and consumption $2 /$ & 4.5 & 4.2 & 3.7 & 4.6 & 10.3 & 10.9 & 10.8 & 11.0 & 11.0 & 11.0 & 11.0 \\
\hline Taxes on international trade and transactions 2 & 10.4 & 9.8 & 9.1 & 8.6 & 6.1 & 5.5 & 5.5 & 5.5 & 5.5 & 5.5 & 5.5 \\
\hline Nontax revenue $3 /$ & 6.3 & 6.1 & 7.7 & 9.4 & 10.4 & 9.6 & 5.2 & 5.6 & 5.6 & 5.5 & 5.5 \\
\hline Capital revenue & 0.0 & 0.0 & 0.0 & 0.0 & 0.0 & 0.1 & 0.0 & 0.0 & 0.0 & 0.0 & 0.0 \\
\hline Total expenditure and net lending & 32.9 & 32.5 & 35.6 & 38.8 & 37.7 & 36.5 & 33.1 & 31.4 & 30.7 & 30.5 & 30.7 \\
\hline Current expenditure & 26.7 & 27.3 & 30.4 & 31.7 & 32.5 & 32.4 & 27.2 & 26.3 & 25.6 & 25.4 & 25.6 \\
\hline Wages and salaries & 10.0 & 10.2 & 12.6 & 12.3 & 11.8 & 11.7 & 11.2 & 10.7 & 10.4 & 10.2 & 10.2 \\
\hline Goods and services $3 /$ & 7.6 & 7.6 & 8.1 & 9.3 & 9.7 & 10.1 & 5.4 & 5.2 & 5.1 & 5.1 & 5.1 \\
\hline Interest & 6.3 & 6.4 & 6.6 & 7.0 & 7.1 & 6.7 & 6.4 & 6.8 & 6.7 & 6.7 & 6.9 \\
\hline Domestic & 4.2 & 4.3 & 4.4 & 4.8 & 5.3 & 5.4 & 5.1 & 5.8 & 6.0 & 6.0 & 6.3 \\
\hline Foreign & 2.1 & 2.1 & 2.2 & 2.2 & 1.8 & 1.4 & 1.2 & 0.9 & 0.7 & 0.6 & 0.6 \\
\hline Transfers & 2.9 & 3.0 & 3.2 & 3.1 & 4.0 & 3.8 & 4.2 & 3.7 & 3.5 & 3.4 & 3.4 \\
\hline Net lending & 0.7 & 0.8 & 0.4 & 0.3 & 0.1 & 0.1 & 0.0 & 0.0 & 0.0 & 0.0 & 0.0 \\
\hline Capital expenditure & 5.4 & 4.5 & 4.7 & 6.8 & 5.1 & 4.1 & 5.8 & 5.0 & 5.0 & 5.0 & 5.0 \\
\hline Current balance & 1.0 & 0.0 & -1.4 & -3.5 & -0.7 & -1.5 & -1.1 & 0.7 & 1.3 & 1.6 & 1.3 \\
\hline Overall balance (before grants) & -5.1 & -5.3 & -6.5 & -10.6 & -5.8 & -5.6 & -7.0 & -4.4 & -3.7 & -3.5 & -3.8 \\
\hline Grants & 1.5 & 1.4 & 3.6 & 2.8 & 2.7 & 3.5 & 4.0 & 2.3 & 0.3 & 0.3 & 0.2 \\
\hline Overall balance (after grants) & -3.5 & -3.9 & -2.9 & -7.8 & -3.1 & -2.1 & -3.0 & -2.1 & -3.5 & -3.2 & -3.5 \\
\hline Primary balance & 2.7 & 2.6 & 3.7 & -0.8 & 3.9 & 4.6 & 3.4 & 4.7 & 3.2 & 3.4 & 3.4 \\
\hline Financing & 3.6 & 2.9 & 5.1 & 10.7 & -5.8 & 2.1 & -11.0 & -4.3 & -0.8 & -1.5 & -3.5 \\
\hline Net foreign financing & -1.2 & 3.5 & 0.2 & 1.3 & -3.0 & 0.7 & -4.1 & -4.9 & -1.9 & -3.3 & -2.7 \\
\hline Drawings & 1.3 & 5.2 & 1.7 & 2.3 & 0.4 & 5.8 & 0.2 & 0.1 & 0.1 & 0.0 & 0.0 \\
\hline Amortization 4/ & 2.6 & 1.7 & 1.6 & 1.0 & 3.4 & 5.1 & 4.3 & 5.0 & 2.0 & 3.3 & 2.7 \\
\hline Net domestic financing & 2.8 & -4.4 & 2.1 & 6.2 & -3.0 & -4.4 & 0.4 & 0.4 & 0.7 & 1.4 & -1.2 \\
\hline Banking system & 1.4 & -6.7 & 0.9 & 5.6 & 0.0 & -5.2 & 0.0 & 0.0 & 0.3 & 1.0 & -1.6 \\
\hline o/w: Principal repayments of SSMC debt & 0.0 & 0.0 & 0.0 & 0.0 & 0.0 & -3.0 & 0.0 & 0.0 & 0.0 & 0.0 & -2.3 \\
\hline Nonbanks and other & 1.4 & 2.3 & 1.2 & 0.6 & -3.0 & 0.8 & 0.4 & 0.4 & 0.4 & 0.4 & 0.4 \\
\hline Sale/purchase of assets & 2.0 & 3.1 & 1.7 & 0.7 & 0.2 & 3.2 & 0.2 & 0.2 & 0.4 & 0.4 & 0.4 \\
\hline Change in arrears & & & & & $\ldots$ & 2.5 & -7.5 & 0.0 & 0.0 & 0.0 & 0.0 \\
\hline o/w: unpaid fuel expenses 5/ & $\ldots$ & 0.7 & 1.1 & 2.5 & $\ldots$ & 1.6 & -7.5 & 0.0 & 0.0 & 0.0 & 0.0 \\
\hline Statistical discrepancy & 0.0 & 1.0 & -2.2 & -2.9 & 0.0 & 0.0 & 0.0 & 0.0 & 0.0 & 0.0 & 0.0 \\
\hline Financing gap & $\ldots$ & $\ldots$ & $\ldots$ & $\ldots$ & 8.9 & 0.0 & 14.0 & 6.4 & 4.3 & 4.7 & 7.0 \\
\hline \multicolumn{12}{|l|}{ Memorandum items: } \\
\hline Stock of unpaid fuel expenses $5 /$ & $\ldots$ & 0.7 & 1.9 & 6.5 & 3.9 & 7.8 & 0.0 & 0.0 & 0.0 & 0.0 & 0.0 \\
\hline $\begin{array}{l}\text { Public sector debt (end of period) } 5 / \\
\text { Of which }\end{array}$ & 134.0 & 128.4 & 145.1 & 163.0 & 149.5 & 151.3 & 148.2 & 143.0 & 138.5 & 133.4 & 128.9 \\
\hline Central government 6 / & 101.5 & 97.9 & 111.5 & 127.4 & 118.0 & 120.0 & 118.1 & 114.3 & 111.3 & 107.8 & 104.7 \\
\hline Domestic & 72.5 & 67.6 & 78.3 & 90.3 & 84.7 & 79.1 & 87.8 & 89.3 & 88.6 & 88.5 & 88.0 \\
\hline External $5 /$ & 29.0 & 30.3 & 33.3 & 37.1 & 33.3 & 40.9 & 30.2 & 25.0 & 22.7 & 19.3 & 16.8 \\
\hline
\end{tabular}

Sources: St. Kitts and Nevis authorities; and Fund staff estimates and projections.

1/ Combined accounts of the Federal Government of St. Kitts and Nevis and the Nevis Island Administration.

2/ The sharp drop in international taxes and concurrent rise in taxes on domestic goods and services reflect the introduction of VAT in November 2010.

3/ The sharp drop in 2012 reflects the corporatization of the Electricity Department in August 2011.

4/ Includes amortization for three public enterprises equivalent to EC\$19.9million in 2011.

5/ Estimates for 2008 and 2009. The authorities have hired international auditors to audit and reconcile the stock of arrears.

6/ Reflects the updated series for the stock of budgetary arrears from 2010. 
Table 4. St. Kitts and Nevis: Structure of the Public Debt, 2005-10 1/

(In millions of U.S. dollars, unless otherwise stated)

\begin{tabular}{|c|c|c|c|c|c|c|}
\hline & 2005 & 2006 & 2007 & 2008 & 2009 & 2010 \\
\hline Total stock of debt & 857.8 & 914.6 & 923.6 & 950.1 & 999.2 & 1073.5 \\
\hline (In percent of GDP) & 159.9 & 145.3 & 134.0 & 128.4 & 145.1 & 159.5 \\
\hline Total external debt (by debtor) & 335.1 & 329.3 & 301.3 & 322.9 & 320.1 & 339.9 \\
\hline St. Kitts Government & 177.2 & 181.8 & 171.0 & 199.8 & 202.0 & 232.1 \\
\hline Nevis Island Administration & 47.0 & 44.1 & 40.8 & 36.4 & 39.4 & 29.7 \\
\hline Public enterprises 2/ & 110.9 & 103.4 & 89.5 & 86.7 & 78.7 & 78.1 \\
\hline Total external debt (by creditor) & 335.1 & 329.3 & 301.3 & 322.9 & 320.1 & 339.9 \\
\hline Bilateral & 39.9 & 44.6 & 42.5 & 38.0 & 33.8 & 30.1 \\
\hline Taiwan, Province of China & 15.3 & 24.0 & 24.9 & 23.0 & 21.1 & 18.9 \\
\hline Kuwait & 9.9 & 8.4 & 7.7 & 6.2 & 4.9 & 4.5 \\
\hline Other & 14.7 & 12.3 & 9.9 & 8.8 & 7.8 & 6.6 \\
\hline Multilateral & 98.9 & 105.6 & 106.6 & 115.0 & 119.8 & 124.3 \\
\hline CDB & 79.8 & 84.3 & 86.1 & 95.2 & 97.4 & 105.3 \\
\hline World Bank & 13.0 & 14.6 & 14.8 & 14.6 & 13.5 & 11.1 \\
\hline Other & 6.1 & 6.7 & 5.8 & 5.2 & 9.0 & 7.9 \\
\hline Commercial and other & 196.4 & 179.0 & 223.4 & 234.8 & 224.7 & 185.6 \\
\hline Total domestic debt (by debtor) & 522.7 & 585.3 & 622.3 & 627.2 & 679.1 & 733.5 \\
\hline St. Kitts Government & 281.1 & 418.8 & 428.5 & 416.0 & 439.7 & 467.4 \\
\hline Nevis Island Administration & 36.6 & 40.2 & 59.2 & 72.3 & 87.0 & 104.2 \\
\hline Public enterprises 2/ & 204.9 & 126.3 & 134.6 & 138.9 & 152.3 & 161.9 \\
\hline Total domestic debt (by instruments) & 522.7 & 585.3 & 622.3 & 627.2 & 682.4 & 747.2 \\
\hline Loans and advances & 333.7 & 404.7 & 448.4 & 410.6 & 458.8 & 505.5 \\
\hline Treasury bills & 152.4 & 144.0 & 136.1 & 146.7 & 154.8 & 174.8 \\
\hline Debentures & 8.8 & 10.3 & 10.3 & 42.4 & 42.3 & 39.9 \\
\hline Regional government securities market & 15.7 & 15.7 & 15.7 & 15.4 & 15.4 & 15.4 \\
\hline Other & 12.1 & 10.6 & 11.8 & 12.1 & 11.2 & 11.6 \\
\hline Total domestic debt (by creditor) & 522.7 & 585.3 & 622.3 & 627.2 & 682.4 & 747.2 \\
\hline ECCB & 6.2 & 6.4 & 6.9 & 4.7 & 11.0 & 10.4 \\
\hline Commercial banks & 362.5 & 424.0 & 448.7 & 436.2 & 461.1 & 504.9 \\
\hline of which: overdrafts & 473.0 & 855.3 & 872.5 & 900.1 & 950.6 & 996.3 \\
\hline Social security & 79.6 & 83.5 & 84.5 & 94.5 & 110.1 & 114.1 \\
\hline Other & 74.4 & 71.5 & 82.3 & 91.9 & 100.2 & 117.8 \\
\hline \multicolumn{7}{|l|}{ Memorandum items (in percent of GDP): } \\
\hline Debt of former St. Kitts Sugar Manufacturing Corporation & 19.8 & 20.6 & 18.8 & 17.4 & 18.7 & 19.2 \\
\hline Public sector debt excluding debt to social security system & 140.1 & 124.7 & 115.2 & 110.9 & 126.3 & 140.3 \\
\hline Net assets of Social Security Board & 52.3 & 49.0 & 48.9 & 49.6 & 57.5 & 62.9 \\
\hline
\end{tabular}

Sources: St. Kitts and Nevis authorities; ECCB; and financial statements of public enterprises.

1/ Public debt comprises debts of the St. Kitts government, Nevis Island Administration, and public enterprises, including government guaranteed debt and debt to the social security system but excluding all other intra-public sector debt.

2/ Including SSMC in 2005. 
Table 5. St Kitts and Nevis: Balance of Payments, 2007-16

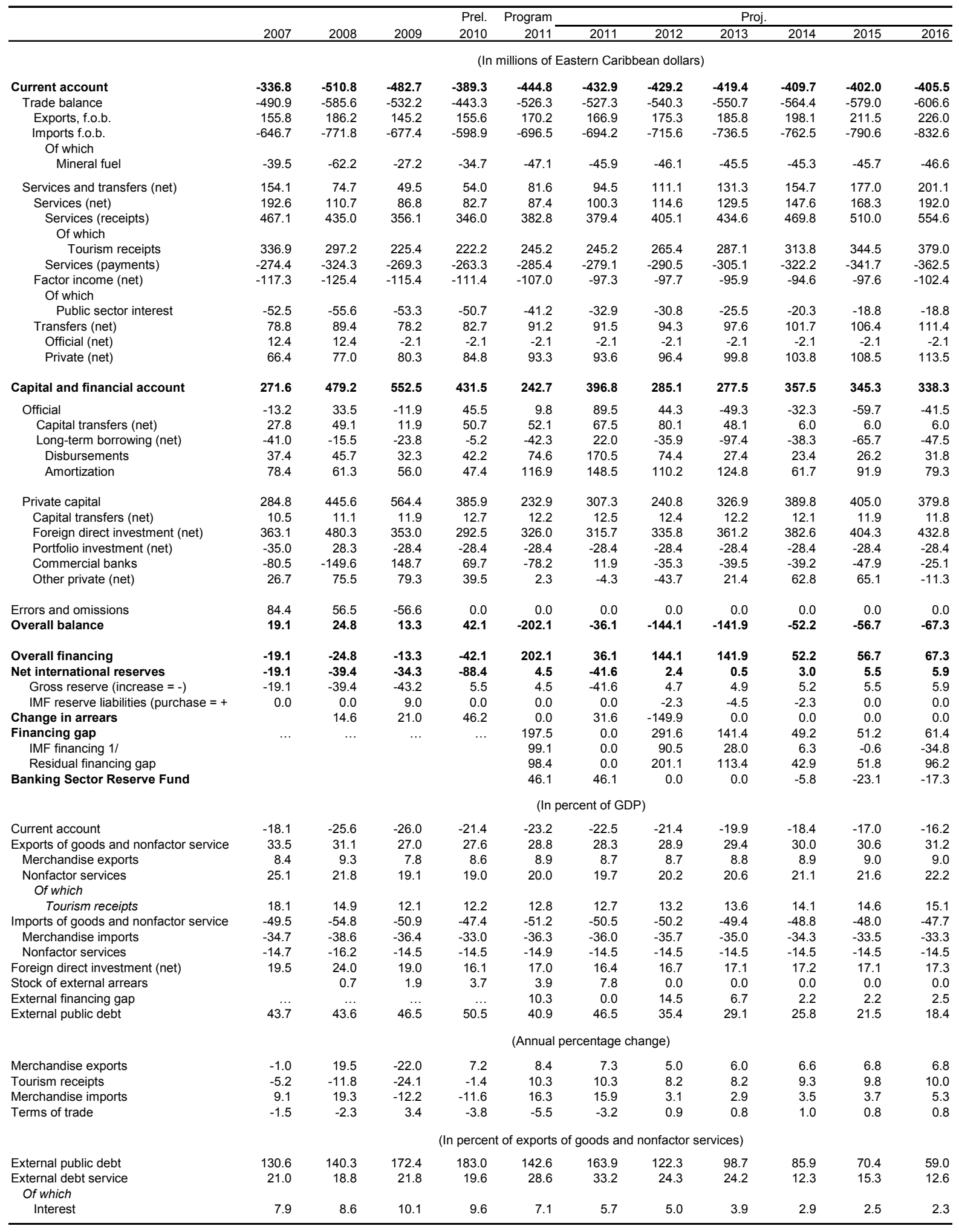

Sources: ECCB; and Fund staff estimates and projections.

$1 /$ Negative indicates repayment to the IMF. 
Table 6. St. Kitts and Nevis: Monetary Survey, 2006-12

\begin{tabular}{|c|c|c|c|c|c|c|c|}
\hline & 2006 & 2007 & 2008 & 2009 & $\begin{array}{r}\text { Prel. } \\
2010 \\
\end{array}$ & $\begin{array}{r}\text { Proj. } \\
2011 \\
\end{array}$ & $\begin{array}{r}\text { Proj. } \\
2012 \\
\end{array}$ \\
\hline \multicolumn{8}{|c|}{ (In millions of EC\$) } \\
\hline Net foreign assets & 562.1 & 661.7 & 850.7 & 711.5 & 730.1 & 819.9 & 850.5 \\
\hline ECCB imputed reserves & 239.1 & 258.3 & 297.6 & 331.9 & 420.3 & 521.9 & 517.2 \\
\hline Crown agents & 10.6 & 10.6 & 10.6 & 10.6 & 10.6 & 10.6 & 10.6 \\
\hline Commercial banks & 312.3 & 392.8 & 542.4 & 369.0 & 299.2 & 287.4 & 322.7 \\
\hline Net domestic assets & 889.7 & 963.0 & 799.8 & 1036.4 & 1172.6 & 1197.5 & 1248.9 \\
\hline Net credit to the public sector & 392.1 & 393.4 & 366.3 & 390.9 & 476.4 & 406.8 & 406.0 \\
\hline Net credit to central government & 422.5 & 464.8 & 337.2 & 427.4 & 850.8 & 790.6 & 790.6 \\
\hline Net credit to St. Kitts & 397.5 & 412.5 & 263.0 & 298.9 & 676.6 & 584.8 & 584.8 \\
\hline Net credit to Nevis & 25.0 & 52.2 & 74.2 & 128.5 & 174.3 & 205.8 & 205.8 \\
\hline Net credit to non-financial public sector & -30.3 & -71.4 & 29.1 & -36.5 & -374.5 & -383.8 & -384.6 \\
\hline Credit to the private sector $1 /$ & 1048.9 & 1173.4 & 1242.7 & 1311.1 & 1356.6 & 1394.2 & 1446.4 \\
\hline Net other assets $2 /$ & -551.3 & -603.8 & -809.2 & -665.6 & -660.4 & -603.5 & -603.5 \\
\hline Broad money (M2) & 1451.8 & 1624.7 & 1650.5 & 1747.9 & 1902.7 & 2017.4 & 2099.4 \\
\hline Money & 201.5 & 226.0 & 251.7 & 243.9 & 349.0 & 370.1 & 385.1 \\
\hline Currency in circulation & 55.1 & 56.2 & 70.1 & 78.3 & 101.1 & 107.1 & 111.5 \\
\hline Demand deposits 1/ & 146.3 & 169.8 & 181.6 & 165.5 & 248.0 & 262.9 & 273.6 \\
\hline Quasi-money 1/ & 1250.3 & 1398.6 & 1398.8 & 1504.0 & 1553.7 & 1647.3 & 1714.3 \\
\hline Savings deposits & 521.8 & 565.6 & 602.6 & 638.5 & 638.4 & 676.9 & 704.4 \\
\hline Time deposits & 309.5 & 377.6 & 398.1 & 491.0 & 552.4 & 585.7 & 609.5 \\
\hline Foreign currency deposits & 419.0 & 455.4 & 398.1 & 374.5 & 362.8 & 384.7 & 400.4 \\
\hline \multicolumn{8}{|c|}{ (Percentage change relative to broad money at beginning of period) } \\
\hline Net foreign assets & 6.4 & 6.9 & 11.6 & -8.4 & 1.1 & 4.7 & 1.5 \\
\hline Net domestic assets & 7.3 & 5.0 & -10.0 & 14.3 & 7.8 & 1.3 & 2.5 \\
\hline Net credit to the public sector & 5.8 & 0.1 & -1.7 & 1.5 & 4.9 & -3.7 & 0.0 \\
\hline Net credit to central government & 5.5 & 2.9 & -7.9 & 5.5 & 24.2 & -3.2 & 0.0 \\
\hline Net credit to non-financial public sector & 0.3 & -2.8 & 6.2 & -4.0 & -19.3 & -0.5 & 0.0 \\
\hline Credit to the private sector $1 /$ & 8.4 & 8.6 & 4.3 & 4.1 & 2.6 & 2.0 & 2.6 \\
\hline Net other assets $2 /$ & -7.0 & -3.6 & -12.6 & 8.7 & 0.3 & 3.0 & 0.0 \\
\hline \multicolumn{8}{|c|}{ (Annual percentage change) } \\
\hline Broad money (M2) & 13.6 & 11.9 & 1.6 & 5.9 & 8.9 & 6.0 & 4.1 \\
\hline Money & 14.5 & 12.2 & 11.4 & -3.1 & 43.1 & 6.0 & 4.1 \\
\hline Currency in circulation & 10.5 & 2.0 & 24.8 & 11.7 & 29.0 & 6.0 & 4.1 \\
\hline Demand deposits 1/ & 16.1 & 16.1 & 6.9 & -8.8 & 49.8 & 6.0 & 4.1 \\
\hline Quasi-money 1/ & 13.5 & 11.9 & 0.0 & 7.5 & 3.3 & 6.0 & 4.1 \\
\hline Savings deposits & 10.8 & 8.4 & 6.5 & 6.0 & 0.0 & 0.0 & 0.0 \\
\hline Time deposits & 7.6 & 22.0 & 5.4 & 23.3 & 12.5 & 0.0 & 0.0 \\
\hline Foreign currency deposits & 22.2 & 8.7 & -12.6 & -5.9 & -3.1 & 0.0 & 0.0 \\
\hline Credit to the private sector (in nominal terms) & 11.5 & 11.9 & 5.9 & 5.5 & 3.5 & 2.8 & 3.7 \\
\hline Credit to the private sector (in real terms) & 3.3 & 8.8 & 1.4 & 4.3 & -1.5 & 1.4 & 1.5 \\
\hline \multicolumn{8}{|l|}{ Memorandum items: } \\
\hline Income velocity of money & 8.4 & 8.2 & 7.9 & 7.6 & 5.2 & 5.2 & 5.2 \\
\hline Income velocity of broad money & 1.2 & 1.1 & 1.2 & 1.1 & 1.0 & 1.0 & 1.0 \\
\hline Private sector credit/GDP (in percent) & 61.7 & 63.0 & 62.2 & 70.5 & 74.6 & 72.3 & 72.1 \\
\hline Foreign currency deposits/GDP (in percent) & 24.7 & 24.5 & 19.9 & 20.1 & 20.0 & 20.0 & 20.0 \\
\hline
\end{tabular}

Sources: ECCB; and Fund staff estimates and projections.

1/ Data up to 2008 is revised to reflect the changes in the definition of private sector in January 2009

$2 /$ Includes capital accounts. 
Table 7. St. Kitts and Nevis: Indicators of External and Financial Vulnerability, 2005-10

(12-month percentage change, unless otherwise stated)

\begin{tabular}{|c|c|c|c|c|c|c|}
\hline & 2005 & 2006 & 2007 & 2008 & 2009 & $\begin{array}{r}\text { Prel. } \\
2010 \\
\end{array}$ \\
\hline \multicolumn{7}{|l|}{ External indicators } \\
\hline Merchandise exports & 8.0 & -8.2 & -1.0 & 19.5 & -22.0 & 7.2 \\
\hline Merchandise imports & 15.2 & 18.6 & 9.1 & 19.3 & -12.2 & -11.6 \\
\hline Terms of trade deterioration (-) & -2.4 & -3.7 & -1.5 & -2.3 & 3.4 & -3.8 \\
\hline Tourism earnings & 18.0 & 8.7 & -5.2 & -11.8 & -24.1 & -1.4 \\
\hline Current account balance (percent of GDP) & -14.9 & -15.8 & -18.1 & -25.6 & -26.0 & -21.4 \\
\hline $\begin{array}{l}\text { Capital and financial account balance (percent of GDP) 1/ } \\
\text { Of which }\end{array}$ & 9.8 & 13.8 & 14.6 & 24.0 & 29.7 & 23.7 \\
\hline Foreign direct investment & 17.3 & 17.5 & 19.5 & 24.0 & 19.0 & 16.1 \\
\hline \multicolumn{7}{|l|}{ Gross international reserves of the ECCB } \\
\hline In millions of U.S. dollars & 600.8 & 696.0 & 764.5 & 759.0 & 800.8 & 926.1 \\
\hline In percent of broad money & 17.9 & 18.6 & 18.6 & 17.0 & 17.5 & 19.7 \\
\hline Commercial banks' net foreign assets (millions of U. S. dollars) & 102.6 & 115.7 & 145.5 & 200.9 & 136.7 & 110.8 \\
\hline External public debt (percent of GDP) & 62.5 & 52.3 & 43.7 & 43.6 & 46.5 & 50.5 \\
\hline $\begin{array}{l}\text { External debt service (in percent of exports of goods and services } \\
\text { Of which }\end{array}$ & 22.0 & 22.7 & 21.0 & 18.8 & 21.8 & 19.6 \\
\hline Interest & 9.5 & 8.8 & 7.9 & 8.6 & 10.1 & 9.6 \\
\hline Nominal exchange rate (E.C. dollars per U.S. dollar, end period) & 2.7 & 2.7 & 2.7 & 2.7 & 2.7 & 2.7 \\
\hline Real effective exchange rate depreciation (-), end period $2 /$ & 2.8 & 2.2 & -5.5 & 12.8 & -3.8 & -5.6 \\
\hline \multicolumn{7}{|l|}{ Financial indicators } \\
\hline Broad money & 6.6 & 13.6 & 11.9 & 1.6 & 5.9 & 8.9 \\
\hline Credit to the private sector & 7.9 & 11.5 & 11.9 & 5.9 & 5.5 & 3.5 \\
\hline Share of nonperforming assets to total assets of banks (percent) & 8.1 & 6.7 & 5.7 & 5.5 & 4.1 & 5.3 \\
\hline Provisions for loan losses/nonperforming assets (percent) & 19.3 & 24.3 & 23.9 & 20.0 & 48.9 & 42.2 \\
\hline Provisions for loan losses/total loans (percent) & 1.2 & 1.2 & 1.0 & 0.9 & 2.1 & 2.3 \\
\hline Gross government exposure/total assets (percent) & 30.1 & 31.0 & 29.1 & 28.2 & 26.1 & 26.3 \\
\hline Total loans/total deposits (percent) & 80.4 & 85.1 & 86.9 & 88.7 & 77.4 & 78.1 \\
\hline Net liquid assets/total deposits (percent) & 38.4 & 38.3 & 38.0 & 42.3 & 42.9 & 41.0 \\
\hline Foreign currency deposits/total deposits (percent) & 21.1 & 25.0 & 23.4 & 22.9 & 30.2 & 27.5 \\
\hline Liquid assets/total deposits (percent) & 39.7 & 40.0 & 38.1 & 39.6 & 43.8 & 41.7 \\
\hline Liquid assets/current liabilities (percent) & 53.1 & 45.4 & 47.6 & 48.5 & 51.1 & 51.3 \\
\hline Total capital/total assets (percent) $3 /$ & 7.6 & 8.0 & 9.5 & 12.3 & 12.3 & 11.6 \\
\hline Total Capital/Risk Weighted Assets (percent) 3/ & 45.1 & 38.9 & 41.8 & 47.0 & 51.0 & 45.6 \\
\hline Tier 1 Capital/Risk Weighted Assets (percent) 3/ & 41.1 & 36.0 & 37.7 & 40.1 & 42.0 & 36.8 \\
\hline Ratio of bank's before-tax profits to average assets (percent) & 3.1 & 3.4 & 4.0 & 4.7 & 2.1 & 1.1 \\
\hline
\end{tabular}

Sources: ECCB; Ministry of Finance; and Fund staff estimates.

$1 /$ Includes errors and omissions.

2/ Estimated on the basis of weights given by the average trade share during 1999-2003.

3 / For locally incorporated banks only. 
Table 8. St. Kitts and Nevis: External Financing Requirement and Sources, 2009-16 (In millions of U.S. dollars)

\begin{tabular}{|c|c|c|c|c|c|c|c|c|}
\hline & & Prel. & & & Proje & & & \\
\hline & 2009 & $2010^{-}$ & 2011 & 2012 & 2013 & 2014 & 2015 & 2016 \\
\hline Gross financing requirement & 127.8 & 154.0 & 210.4 & 227.0 & 206.5 & 158.6 & 155.2 & 177.0 \\
\hline Current account deficit & 178.8 & 144.2 & 159.8 & 157.9 & 153.8 & 150.0 & 147.3 & 149.6 \\
\hline Amortization & -63.7 & -22.9 & 52.2 & 70.1 & 52.9 & 9.7 & 9.9 & 29.5 \\
\hline $\begin{array}{l}\text { Official (public sector and central g } \\
\text { of which: to official creditors }\end{array}$ & 20.8 & 17.6 & 55.0 & 40.8 & 46.2 & 18.4 & 16.3 & 16.1 \\
\hline Private sector (net) & -84.4 & -40.4 & -2.8 & 29.2 & 6.7 & -8.7 & -6.4 & 13.5 \\
\hline Commercial banks & -55.1 & -25.8 & -4.4 & 13.1 & 14.6 & 14.5 & 17.7 & 9.3 \\
\hline Other private & -29.4 & -14.6 & 1.6 & 16.2 & -7.9 & -23.3 & -24.1 & 4.2 \\
\hline Reserve accumulation (+: increase) & 12.7 & 32.7 & -1.7 & -0.9 & -0.2 & -1.1 & -2.0 & -2.2 \\
\hline Sources of financing & 141.0 & 136.9 & 163.7 & 175.6 & 155.7 & 146.6 & 155.5 & 168.1 \\
\hline Capital grants and transfers & 8.8 & 23.5 & 29.6 & 34.2 & 22.3 & 6.7 & 6.6 & 6.6 \\
\hline Foreign Direct Investment (net) & 130.8 & 108.3 & 116.9 & 124.4 & 133.8 & 141.7 & 149.7 & 160.3 \\
\hline Net inflow of equity and other capital & -10.5 & -10.5 & -10.5 & -10.5 & -10.5 & -10.5 & -10.5 & -10.5 \\
\hline New borrowing & 11.9 & 15.6 & 27.7 & 27.5 & 10.1 & 8.7 & 9.7 & 11.8 \\
\hline of which: public sector & 11.9 & 15.6 & 27.7 & 27.5 & 10.1 & 8.7 & 9.7 & 11.8 \\
\hline Financing gap & -13.2 & 17.1 & 46.7 & 51.4 & 50.8 & 12.0 & -0.4 & 8.9 \\
\hline Errors and omissions & -20.9 & 0.0 & 0.0 & 0.0 & 0.0 & 0.0 & 0.0 & 0.0 \\
\hline Accumulation of arrears & 7.8 & 17.1 & 11.7 & -55.5 & 0.0 & 0.0 & 0.0 & 0.0 \\
\hline Exceptional external financing & 0.0 & 0.0 & 35.0 & 32.5 & 8.8 & -1.5 & -28.1 & -33.2 \\
\hline IMF net disbursement & 0.0 & 0.0 & 35.0 & 32.5 & 8.8 & -1.5 & -28.1 & -33.2 \\
\hline Fund disbursement & 0.0 & 0.0 & 35.4 & 33.5 & 10.4 & 4.7 & 0.0 & 0.0 \\
\hline Repurchases & 0.0 & 0.0 & 0.0 & 0.0 & 0.0 & -4.4 & -26.5 & -32.6 \\
\hline Interest due & 0.0 & 0.0 & -0.5 & -1.1 & -1.6 & -1.8 & -1.6 & -0.6 \\
\hline Other new financing & 0.0 & 0.0 & 0.0 & 0.0 & 0.0 & 0.0 & 0.0 & 0.0 \\
\hline Residual financing gap & 0.0 & 0.0 & 0.0 & 74.5 & 42.0 & 13.5 & 27.7 & 42.1 \\
\hline
\end{tabular}

Sources: St. Kitts and Nevis authorities; Eastern Caribbean Central Bank; and Fund staff estimates and projections. 
Table 9: St.Kitts and Nevis: Indicators of Capacity to Repay the Fund, 2012-21 1/

\begin{tabular}{|c|c|c|c|c|c|c|c|c|c|c|}
\hline & 2012 & 2013 & 2014 & 2015 & 2016 & 2017 & 2018 & 2019 & 2020 & 2021 \\
\hline \multicolumn{11}{|l|}{ Fund obligations based on existing credit } \\
\hline (in millions of SDRs) & 0.85 & 1.39 & 3.59 & 11.26 & 8.36 & 0.00 & 0.00 & 0.00 & 0.00 & 0.00 \\
\hline Principal & 0.56 & 1.11 & 3.33 & 11.08 & 8.31 & 0.00 & 0.00 & 0.00 & 0.00 & 0.00 \\
\hline Charges and interest & 0.29 & 0.28 & 0.26 & 0.18 & 0.05 & 0.00 & 0.00 & 0.00 & 0.00 & 0.00 \\
\hline \multicolumn{11}{|l|}{ Fund obligations based on existing and prospective credit (in } \\
\hline millions of SDRs) & 1.22 & 2.09 & 4.43 & 17.55 & 20.74 & 9.09 & 3.13 & 0.71 & 0.00 & 0.00 \\
\hline Principal & 0.56 & 1.11 & 3.33 & 16.56 & 20.38 & 8.98 & 3.10 & 0.71 & 0.00 & 0.00 \\
\hline Charges and interest & 0.66 & 0.98 & 1.10 & 0.99 & 0.36 & 0.11 & 0.03 & 0.00 & 0.00 & 0.00 \\
\hline \multicolumn{11}{|l|}{ Fund credit outstanding based on existing and prospective } \\
\hline credit (in millions of SDRs) & 44.8 & 50.1 & 49.7 & 33.2 & 12.8 & 3.8 & 0.7 & 0.0 & 0.0 & 0.0 \\
\hline \multicolumn{11}{|l|}{ Total Obligations based on existing and prospective credit } \\
\hline in millions of U.S. dollars2/ & 2.0 & 3.3 & 7.1 & 28.1 & 33.2 & 14.5 & 5.0 & 1.1 & 0.0 & 0.0 \\
\hline in percent of exports of goods and services & 0.9 & 1.5 & 2.9 & 10.5 & 11.5 & 4.8 & 1.6 & 0.3 & 0.0 & 0.0 \\
\hline in percent of external debt service $3 /$ & 3.6 & 5.7 & 18.9 & 40.7 & 47.7 & 36.7 & 16.0 & 4.0 & 0.0 & 0.0 \\
\hline in percent of GDP & 0.3 & 0.4 & 0.9 & 3.2 & 3.6 & 1.5 & 0.5 & 0.1 & 0.0 & 0.0 \\
\hline in percent of quota & 13.7 & 23.5 & 49.8 & 197.2 & 233.0 & 102.1 & 35.2 & 8.0 & 0.0 & 0.0 \\
\hline in percent of net imputed reserves & 1.2 & 2.0 & 4.3 & 17.2 & 20.6 & 9.0 & 3.1 & 0.7 & 0.0 & 0.0 \\
\hline in percent of revenue and grants & 0.9 & 1.5 & 3.2 & 11.8 & 13.2 & 5.4 & 1.8 & 0.4 & 0.0 & 0.0 \\
\hline \multicolumn{11}{|l|}{ Outstanding Fund Credit } \\
\hline in millions of U.S. dollars2/ & 71.6 & 80.2 & 79.6 & 53.1 & 20.5 & 6.1 & 1.1 & 0.0 & 0.0 & 0.0 \\
\hline in percent of exports of goods and services & 33.3 & 34.9 & 32.2 & 19.9 & 7.1 & 2.0 & 0.4 & 0.0 & 0.0 & 0.0 \\
\hline in percent of external debt service3/ & 137.2 & 144.1 & 261.9 & 129.5 & 56.4 & 24.3 & 4.3 & 0.0 & 0.0 & 0.0 \\
\hline in number of months of imports of goods and services & 2.3 & 2.5 & 2.4 & 1.5 & 0.6 & 0.2 & 0.0 & 0.0 & 0.0 & 0.0 \\
\hline in percent of GDP & 9.6 & 10.3 & 9.7 & 6.1 & 2.2 & 0.6 & 0.1 & 0.0 & 0.0 & 0.0 \\
\hline in percent of quota & 503.0 & 563.4 & 558.9 & 372.8 & 143.8 & 42.8 & 8.0 & 0.0 & 0.0 & 0.0 \\
\hline in percent of net imputed reserves & 42.3 & 47.9 & 48.1 & 32.5 & 12.7 & 3.8 & 0.7 & 0.0 & 0.0 & 0.0 \\
\hline Net use of Fund Credit (in millions of SDRs) & 20.4 & 5.4 & -0.4 & -16.6 & -20.4 & -9.0 & -3.1 & -0.7 & 0.0 & 0.0 \\
\hline Disbursements & 21.0 & 6.5 & 2.9 & 0.0 & 0.0 & 0.0 & 0.0 & 0.0 & 0.0 & 0.0 \\
\hline Repayment and Repurchases & 0.6 & 1.1 & 3.3 & 16.6 & 20.4 & 9.0 & 3.1 & 0.7 & 0.0 & 0.0 \\
\hline \multicolumn{11}{|l|}{ Memorandum items: } \\
\hline Nominal GDP (in millions of US dollars) & 742.8 & 780.3 & 823.8 & 873.9 & 927.1 & 983.5 & $1,043.4$ & $1,106.9$ & $1,174.3$ & $1,245.7$ \\
\hline Exports of goods and services (in millions of US dollars) & 215.0 & 229.8 & 247.4 & 267.2 & 289.1 & 304.2 & 320.2 & 337.1 & 355.0 & 373.9 \\
\hline External debt service (in millions of US dollars) & 52.2 & 55.7 & 30.4 & 41.0 & 36.3 & 25.1 & 26.2 & 27.6 & 27.2 & 27.5 \\
\hline Imports of goods and services (in millions of US dollars) & 372.6 & 385.8 & 401.7 & 419.4 & 442.7 & 453.3 & 464.4 & 482.6 & 501.5 & 521.3 \\
\hline Net imputed reserves (in millions of US dollars) & 169.3 & 167.5 & 165.6 & 163.5 & 161.4 & 161.4 & 161.4 & 161.4 & 161.4 & 161.4 \\
\hline
\end{tabular}

1/ Assumes a 3-year SBA with access in the amount of SDR 52.5 million (590 percent of quota)

$2 /$ US $\$ 1=0.625$ SDR (program exchange rate in TMU)

3 / Including prospective repurchases/repayments 
Table 10. St. Kitts and Nevis: External Debt Sustainability Framework, 2006-16

(In percent of GDP, unless otherwise indicated)

\begin{tabular}{|c|c|c|c|c|c|c|c|c|c|c|c|c|c|c|}
\hline & \multicolumn{5}{|c|}{ Actual } & \multicolumn{9}{|c|}{ Projections } \\
\hline & 2006 & 2007 & 2008 & 2009 & 2010 & & & 2011 & 2012 & 2013 & 2014 & 2015 & 2016 & Debt-stabilizing \\
\hline Baseline: External debt & 52.3 & 43.7 & 43.6 & 46.5 & 50.5 & & & 46.5 & 35.4 & 29.1 & 25.8 & 21.5 & 18.4 & $\begin{array}{l}\text { Irrent account 6/ } \\
-16.6\end{array}$ \\
\hline Change in external debt & -10.2 & -8.6 & -0.1 & 2.9 & 4.0 & & & -4.0 & -11.1 & -6.3 & -3.3 & -4.3 & -3.1 & \\
\hline Identified external debt-creating flows $(4+8+9)$ & -7.0 & -5.2 & -2.6 & 11.1 & 8.1 & & & 7.6 & 5.4 & 3.3 & 1.7 & 0.3 & -0.7 & \\
\hline Current account deficit, excluding interest payments & 12.3 & 15.3 & 22.8 & 23.1 & 18.6 & & & 20.8 & 19.9 & 18.7 & 17.5 & 16.2 & 15.5 & \\
\hline Deficit in balance of goods and services & 13.5 & 16.0 & 23.8 & 24.0 & 19.8 & & & 22.2 & 21.2 & 20.0 & 18.7 & 17.4 & 16.6 & \\
\hline Exports & 37.4 & 33.5 & 31.1 & 27.0 & 27.6 & & & 28.3 & 28.9 & 29.4 & 30.0 & 30.6 & 31.2 & \\
\hline Imports & 50.9 & 49.5 & 54.8 & 50.9 & 47.4 & & & 50.5 & 50.2 & 49.4 & 48.8 & 48.0 & 47.7 & \\
\hline Net non-debt creating capital inflows (negative) & -14.2 & -17.6 & -25.5 & -17.5 & -14.5 & & & -14.9 & -15.3 & -15.8 & -15.9 & -15.9 & -16.2 & \\
\hline Automatic debt dynamics $1 /$ & -5.1 & -2.8 & 0.1 & 5.4 & 4.0 & & & 1.7 & 0.9 & 0.4 & 0.1 & -0.1 & 0.0 & \\
\hline Contribution from nominal interest rate & 3.5 & 2.8 & 2.8 & 2.8 & 2.8 & & & 1.7 & 1.5 & 1.2 & 0.9 & 0.8 & 0.7 & \\
\hline Contribution from real GDP growth & -1.9 & -2.3 & -1.7 & 2.6 & 1.3 & & & 0.0 & -0.7 & -0.8 & -0.8 & -0.9 & -0.7 & \\
\hline Contribution from price and exchange rate changes $2 /$ & -6.8 & -3.2 & -1.1 & 0.0 & -0.1 & & & & & $\ldots$ & & & & \\
\hline Residual, incl. change in gross foreign assets (2-3) 3/ & -3.2 & -3.4 & 2.5 & -8.2 & -4.1 & & & -11.6 & -16.5 & -9.6 & -4.9 & -4.5 & -2.5 & \\
\hline External debt-to-exports ratio (in percent) & 139.7 & 130.6 & 140.3 & 172.4 & 183.0 & & & 163.9 & 122.3 & 98.7 & 85.9 & 70.4 & 59.0 & \\
\hline Gross external financing need (in billions of US dollars) $4 /$ & 0.2 & 0.2 & 0.2 & 0.2 & 0.2 & & & 0.2 & 0.3 & 0.2 & 0.2 & 0.2 & 0.2 & \\
\hline in percent of GDP & 26.2 & 27.1 & 32.7 & 33.7 & 28.8 & 10-Year & 10-Year & 33.3 & 38.8 & 29.2 & 23.9 & 23.4 & 21.4 & \\
\hline Scenario with key variables at their historical averages $5 /$ & & & & & & & & 46.5 & 31.5 & 22.8 & 18.4 & 14.3 & 12.0 & -18.8 \\
\hline & & & & & & Historical & Standard & & & & & & & \\
\hline Key Macroeconomic Assumptions Underlying Baseline & & & & & & Average & Deviation & & & & & & & \\
\hline Real GDP growth (in percent) & 3.5 & 5.0 & 4.0 & -5.6 & -2.7 & 2.0 & 4.7 & 0.0 & 1.5 & 2.5 & 3.0 & 3.5 & 3.5 & \\
\hline GDP deflator in US dollars (change in percent) & 12.1 & 6.6 & 2.5 & -0.1 & 0.2 & 2.8 & 4.3 & 6.0 & 2.5 & 2.5 & 2.5 & 2.5 & 2.5 & \\
\hline Nominal external interest rate (in percent) & 6.5 & 5.9 & 6.8 & 6.1 & 5.9 & 6.6 & 0.6 & 3.6 & 3.4 & 3.6 & 3.3 & 3.3 & 3.6 & \\
\hline Growth of exports (US dollar terms, in percent) & 4.0 & -2.1 & -0.3 & -19.3 & 0.1 & 2.7 & 10.6 & 8.9 & 6.2 & 6.9 & 7.6 & 8.0 & 8.2 & \\
\hline Growth of imports (US dollar terms, in percent) & 14.5 & 6.4 & 19.0 & -13.6 & -8.9 & 3.1 & 11.1 & 12.9 & 3.4 & 3.5 & 4.1 & 4.4 & 5.6 & \\
\hline Current account balance, excluding interest payments & -12.3 & -15.3 & -22.8 & -23.1 & -18.6 & -18.4 & 5.4 & -20.8 & -19.9 & -18.7 & -17.5 & -16.2 & -15.5 & \\
\hline Net non-debt creating capital inflows & 14.2 & 17.6 & 25.5 & 17.5 & 14.5 & 19.0 & 6.8 & 14.9 & 15.3 & 15.8 & 15.9 & 15.9 & 16.2 & \\
\hline
\end{tabular}

$1 /$ Derived as $[r-g-\rho(1+g)+\varepsilon \alpha(1+r)] /(1+g+\rho+g \rho)$ times previous period debt stock, with $r=$ nominal effective interest rate on external debt; $\rho=$ change in domestic GDP deflator in US dollar terms, $g=$ real GDP growth rate, $\varepsilon=$ nominal appreciation (increase in dollar value of domestic currency), and $\alpha=$ share of domestic-currency denominated debt in total external debt.

(1) $3 /$ For projection, line includes the impact of price and exchange rate changes.

The as current account defict, plus amortization on mevious period.

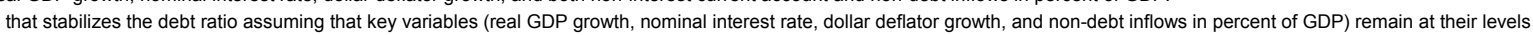

of the last projection year. 
Table 11. St. Kitts and Nevis: Public Sector Debt Sustainability Framework, 2006-16

(In percent of GDP, unless otherwise indicated)

\begin{tabular}{|c|c|c|c|c|c|c|c|c|c|c|c|c|}
\hline & \multicolumn{5}{|c|}{ Actual } & \multicolumn{6}{|c|}{ Projections } & \multirow{3}{*}{$\begin{array}{c}\text { Debt-stabilizing } \\
\text { primary } \\
\text { balance } 9 /\end{array}$} \\
\hline & 2006 & 2007 & 2008 & 2009 & 2010 & 2011 & 2012 & 2013 & 2014 & 2015 & 2016 & \\
\hline & & & & & & & & & & & & \\
\hline Baseline: Public sector debt 1/ & 145.3 & 134.0 & 128.4 & 145.1 & 163.0 & 151.3 & 148.2 & 143.0 & 138.5 & 133.4 & 128.9 & 0.7 \\
\hline $\mathrm{o} / \mathrm{w}$ foreign-currency denominated & 52.3 & 43.7 & 43.6 & 46.5 & 50.5 & 47.2 & 36.1 & 29.7 & 26.5 & 22.2 & 19.0 & \\
\hline Change in public sector debt & -14.6 & -11.3 & -5.6 & 16.7 & 17.9 & -11.7 & -3.1 & -5.2 & -4.5 & -5.1 & -4.5 & \\
\hline Identified debt-creating flows $(4+7+12)$ & -16.0 & -13.5 & -7.1 & 9.0 & 11.1 & -10.2 & -2.9 & -5.0 & -4.2 & -4.8 & -4.2 & \\
\hline Primary deficit & -2.3 & -3.3 & -3.2 & -4.6 & -1.7 & -6.7 & -5.4 & -6.5 & -5.0 & -5.1 & -5.0 & \\
\hline Revenue and grants & 37.3 & 36.0 & 35.3 & 39.6 & 38.0 & 41.4 & 37.1 & 36.2 & 34.2 & 34.1 & 34.1 & \\
\hline Of which contribution from real interest rate & -8.5 & -1.8 & 4.2 & 7.7 & 9.5 & -0.3 & 4.8 & 5.3 & 5.2 & 5.2 & 5.6 & \\
\hline Of which contribution from real GDP growth & -4.8 & -6.5 & -5.1 & 7.6 & 4.0 & 0.0 & -2.2 & -3.5 & -4.1 & -4.6 & -4.4 & \\
\hline Contribution from exchange rate depreciation $4 /$ & 0.0 & 0.0 & 0.0 & 0.0 & 0.0 & & & & & & $\ldots$ & \\
\hline Other identified debt-creating flows & -0.4 & -2.0 & -3.1 & -1.7 & -0.7 & -3.2 & -0.2 & -0.2 & -0.4 & -0.4 & -0.4 & \\
\hline Privatization receipts (negative) & -0.4 & -2.0 & -3.1 & -1.7 & -0.7 & -3.2 & -0.2 & -0.2 & -0.4 & -0.4 & -0.4 & \\
\hline Recognition of implicit or contingent liabilities & 0.0 & 0.0 & 0.0 & 0.0 & 0.0 & 0.0 & 0.0 & 0.0 & 0.0 & 0.0 & 0.0 & \\
\hline Other (specify, e.g. bank recapitalization) & 0.0 & 0.0 & 0.0 & 0.0 & 0.0 & 0.0 & 0.0 & 0.0 & 0.0 & 0.0 & 0.0 & \\
\hline Residual, including asset changes (2-3) 5/ & 1.4 & 2.2 & 1.5 & 7.7 & 6.8 & -1.5 & -0.2 & -0.2 & -0.3 & -0.3 & -0.3 & \\
\hline Public sector debt-to-revenue ratio $1 /$ & 389.7 & 372.3 & 363.4 & 366.3 & 428.9 & 365.6 & 399.7 & 394.7 & 405.2 & 390.8 & 378.0 & \\
\hline Gross financing need $6 /$ & 67.7 & 55.6 & 54.4 & 51.3 & 51.1 & 49.9 & 57.2 & 55.3 & 53.9 & 54.6 & 53.8 & \\
\hline in billions of U.S. dollars & 0.4 & 0.4 & 0.4 & 0.4 & 0.3 & 0.4 & 0.4 & 0.4 & 0.4 & 0.5 & 0.5 & \\
\hline Scenario with key variables at their historical averages $7 /$ & & & & & & 151.3 & 154.7 & 158.1 & 161.3 & 164.5 & 167.7 & 2.1 \\
\hline Scenario with no policy change (constant primary balance) in 2011-2016 & & & & & & 151.3 & 146.9 & 141.5 & 135.4 & 128.6 & 122.4 & 0.7 \\
\hline \multicolumn{13}{|l|}{ Key Macroeconomic and Fiscal Assumptions Underlying Baseline } \\
\hline Real GDP growth (in percent) & 3.5 & 5.0 & 4.0 & -5.6 & -2.7 & 0.0 & 1.5 & 2.5 & 3.0 & 3.5 & 3.5 & \\
\hline Average nominal interest rate on public debt (in percent) 8/ & 6.3 & 5.5 & 6.0 & 5.6 & 6.6 & 5.8 & 5.9 & 6.3 & 6.4 & 6.6 & 7.0 & \\
\hline Average real interest rate (nominal rate minus change in GDP deflator, in percent) & -5.8 & -1.1 & 3.5 & 5.6 & 6.4 & -0.2 & 3.3 & 3.8 & 3.9 & 4.1 & 4.5 & \\
\hline Nominal appreciation (increase in US dollar value of local currency, in percent) & 0.0 & 0.0 & 0.0 & 0.0 & 0.0 & & & & & & & \\
\hline Inflation rate (GDP deflator, in percent) & 12.1 & 6.6 & 2.5 & -0.1 & 0.2 & 6.0 & 2.5 & 2.5 & 2.5 & 2.5 & 2.5 & \\
\hline Growth of real primary spending (deflated by GDP deflator, in percent) & -11.3 & -3.9 & 3.0 & 1.4 & 1.0 & -4.3 & -7.3 & -4.0 & 1.3 & 3.1 & 3.7 & \\
\hline Primary deficit & -2.3 & -3.3 & -3.2 & -4.6 & -1.7 & -6.7 & -5.4 & -6.5 & -5.0 & -5.1 & -5.0 & \\
\hline
\end{tabular}

1/ Public sector covers general government and gross debt is used

2/ Derived as $[(r-\pi(1+g)-g+\alpha \varepsilon(1+r)](1+g+\pi+g \pi))$ times previous period debt ratio, with $r=$ interest rate; $\pi=$ growth rate of GDP deflator; $g=$ real GDP growth rate; $\alpha=$ share of foreign-currency denominated debt; and $\varepsilon=$ nominal exchange rate depreciation (measured by increase in local currency value of U.S. dollar).

$3 /$ The real interest rate contribution is derived from the denominator in footnote $2 /$ as $r-\pi(1+g)$ and the real growth contribution as $-g$.

4/ The exchange rate contribution is derived from the numerator in footnote $2 /$ as $\alpha \varepsilon(1+r)$.

$5 /$ For projections, this line includes exchange rate changes.

Defined as public sector defich, plus amonizalion of medium and long-term public sector debt, plus short-term debt at end of previous period.

7/ The key variables include real GDP growth; real interest rate; and primary balance in percent of GDP.

/ Assumes that key variables (real GDP growth, real interest rate, and other identified debt-creating flows) remain at the level of the last projection year. 


\section{APPENDIX}

Basseterre, St. Kitts

January 12, 2012

Ms. Christine Lagarde

Managing Director

International Monetary Fund

Washington DC, 20431

Dear Ms. Lagarde:

Since the approval of the Stand-By Arrangement in July 2011, economic activity has slowed in St. Kitts and Nevis reflecting the increasingly adverse global environment. With a number of major construction projects in the pipeline and an improvement in tourism activity, prospects for 2012 remain, however, broadly unchanged. In addition, given our prudent macroeconomic management, we are on track to meet our 2011 fiscal targets under the program. This achievement has been possible thanks to the sacrifice and efforts of the people of St. Kitts and Nevis, and with strong support from the donor community and international financial institutions, including the IMF.

Our Letter of Intent (LOI) and Memorandum of Economic and Financial Policies (MEFP) of July 13, 2011, requesting an arrangement under the Fund's Stand-By Arrangement (SBA), outlined the government's strategy under its home-grown medium-term reform program to put public finances on a sustainable trajectory, implement a comprehensive debt restructuring to address the debt overhang, and further strengthen the financial system. While the broad objectives and policies of our economic program remain unchanged from those outlined in the MEFP, we have further refined these policies in the context of the first review of the program.

The Government of St. Kitts and Nevis reaffirms its commitment to making this program a success. The success of the program would not only benefit the people of St. Kitts and Nevis but could also become a model for other countries in the region. Since the SBA was approved in July 2011, we have been determined to move forward with our reform agenda and to successfully implement our policies. This is reflected in the fact that we met our fiscal target, as well as all other quantitative performance criteria and structural benchmarks for end-September 2011, except for the structural benchmarks on the registration/valuation of 600 acres of land and updating the existing stress tests of banks. These three delayed benchmarks, as well as approving the 2012 budget consistent with the program objectives, were made prior actions for the first review and were completed before the end of 2011 . 
Furthermore, we have made progress with our comprehensive debt restructuring process. We welcome your continued strong support for these initiatives.

In the attached Memorandum of Economic and Financial Policies (MEFP) and the Technical Memorandum of Understanding (TMU), we set out our plans to achieve the 2012 objectives laid out in our program supported by the IMF. Based on the strength of these policies, and in light of our performance under the program and our continued commitment, we request the completion of the first program and financing assurances reviews, waiver of applicability for the end-December 2011 performance criteria, and the release of the second tranche of SDR 11.47 million. We also request modification of one PC.

We are confident that the policies set forth in the Letter of Intent of July 13, 2011 and this letter are adequate to achieve the objectives of our program. However, we need to remain vigilant to downside risks of lower-than expected growth in the global economy and the impact on government's revenue and unemployment. We stand ready to take additional corrective actions that may become appropriate for this purpose as circumstances change. We will continue to consult with the Fund on the adoption of such actions in advance of necessary revision of policies contained in this letter and the attached Memorandum, in accordance with the Fund's policies on such consultation.

The Government authorizes the Fund to make public the contents of this letter, the attached MEFP, an accompanying letter from the Governor of the Eastern Caribbean Central Bank, and the Staff Report to clearly communicate our policies and to signal the seriousness of our commitment to the program to the people of St. Kitts and Nevis and the international community.

Sincerely,

$/ \mathrm{s} /$

Rt. Hon. Dr. Denzil Douglas

Prime Minister and Minister of Finance

St. Kitts and Nevis 


\section{Attachment I. Memorandum of Economic and Financial Policies}

1. St. Kitts and Nevis has made important progress in implementing its economic program set forth in our Memorandum of Economic and Financial Policies (MEFP) dated July 13, 2011. Our homegrown economic reform program continues to focus on putting public finances on a sustainable trajectory, implementing a comprehensive debt restructuring to address the debt overhang, and further strengthening the financial system. This MEFP updates these policies in the context of the first review of the SBA.

\section{Performance Under the Program}

2. We have been determined in successfully implementing our policies since the SBA was approved in July 2011 and fulfilled our commitments under the program at endSeptember 2011, including some that were initially delayed. In addition, we are well on track to meet the program's end-December 2011 quantitative and structural reform targets. In this context, we request completion of the first program and financing assurances reviews and waiver of applicability for end-December 2011 performance criteria. We also request clarification on the classification of RGSM bonds as domestic debt for monitoring purposes, and to modify the PC on the central government budget expenditure arrears to exclude the domestic debt service arrears related to the debt restructuring, in line with the design of the external arrears PC.

- Growth and inflation. Real GDP growth in 2011 is estimated to be flat, reflecting the adverse global environment. Notwithstanding the effects of the increase in food and oil prices, the introduction of the VAT, and adjustments in electricity tariffs, year-on-year inflation declined to 1.6 percent at end-November 2011.

- $\quad$ Fiscal policy. Despite the weaker and more volatile global environment, the government's economic program, supported by a Stand-By Arrangement (SBA) by the IMF, has yielded positive results. The overall fiscal deficit at end-September 2011 reached EC $\$ 26.5$ million, which is well above the adjusted program floor, and the primary surplus exceeded the program's indicative floor. We are also on track to observe the program's target on the overall fiscal deficit for 2011 as a whole. The disbursements of the fixed tranches of the programmed EU 2008 and 2009 sugar grants, amounting to $€ 11.3$ million, were made in December 2011.

- Other performance criteria and structural benchmarks. The ceiling on central government budget expenditure arrears, stock of external short-term debt, and on central government or guaranteed external arrears accumulation have all been met. While the registry and valuation of at least 600 acres of land and the update of bank stress tests were initially delayed, they were made prior actions under the first review and have since been completed. Furthermore, the bill for the corporatization of the Electricity Department was approved by Parliament in April 2011. 
- Debt restructuring. Substantial progress has been made with respect to the comprehensive debt restructuring. The process is on track to meet the objectives set out in the program to achieve a substantial debt reduction, close the financing gaps, and put the public debt on a firmly downward trajectory to meet the ECCU target of 60 percent debt-to-GDP ratio by 2020 . We are in active negotiations with external commercial and domestic creditors and have secured financial assurances from the Paris Club in July 2011. At the same time, discussions regarding the resolution of debt owed to domestic creditors are ongoing. In particular, the broad outlines of a Special Purpose Vehicle (SPV) structure that will play an important role in the $\mathrm{debt} /$ land swap envisaged in the program have been determined. Also, in support of the Government's debt restructuring effort, the Caribbean Development Bank's Board approved to partially guarantee debt service payments of the new exchange instruments.

- $\quad$ Financial sector. The domestic banking sector remains well capitalized and liquid. Domestic commercial banks' ratio of net liquid assets-to-total deposits improved slightly from 50.4 percent at end-December 2010 to 52.6 percent at end-September 2011, while the ratio of NPLs has remained relatively low at 5.5 percent compared with 14.8 percent for the ECCU region. Commercial banks' capital adequacy ratio is well above the ECCB's regulatory requirement of 8 percent and there has been no request to access the Banking Sector Reserve Fund (BSRF) set up under the SBA.

3. The fiscal outturn for 2011 is expected to be in line with program targets. Current revenue increased from 28.2 percent of GDP in 2010 to an estimated 30.9 percent of GDP in 2011. Grants amounted to 3.5 percent of GDP, 0.8 percentage points of GDP higher than under the program, reflecting transfers from the Sugar Industry Diversification Foundation. At the same time, total expenditure and net lending decreased from 38.8 percent of GDP in 2010 to an estimated 36.5 percent of GDP. As a result, the overall balance is expected to have reached -2.1 percent of GDP, well below the program target of -3.1 percent of GDP.

\section{Policies During 2012}

\section{The outlook for $\mathbf{2 0 1 2}$ and the medium term remain cautiously optimistic.} Economic growth is projected to reach 1.5 percent in 2012, supported by FDI-related construction projects and an improvement in tourism activity. However, the more adverse global environment continues to highlight increasing downside risks. Our plans, as outlined below, should ensure that our fiscal program for 2012 is in line with the program.

\section{A. Fiscal Policy}

5. Our 2012 fiscal program targets an overall deficit of 3.0 percent of GDP. The external debt service payments made by the central government on behalf of three public enterprises are now included in the current transfers, resulting in the overall deficit target 0.5 percentage 
point of GDP larger than in the original program target. This deficit, along with appropriately prudent fiscal policies in the coming years, will accommodate capital expenditure needed to address pressing development needs, while allowing us to reach our debt target of 60 percent of GDP by 2020.

\section{Revenue}

6. We are taking a number of measures to improve tax compliance. First, we are intensifying auditing of taxpayers to make our tax system fairer and more efficient. Second, we intend to make the threshold on personal income only deductible for the corporate income tax from one cost center in a corporation or other business entity. Third, we plan to improve collection of taxes and guard against the accumulation of arrears. The Inland Revenue Department is also taking steps to improve the collection of tax arrears. To this end, we intend to request TA from our development partners, including the Caribbean Regional Technical Assistance Center (CARTAC), in the following areas: (i) best practices in enhancing strategic planning and performance; (ii) strengthening audit capacity; (iii) collections training; (iv) taxpayer services training; and (v) a new tax administration review.

7. In addition, we will avoid eroding the tax base. We will continue to employ the oil price pass-through mechanism, which incorporates adjustments on a regular basis.

\section{Spending}

8. Achieving our 2012 fiscal target requires exerting tight control over expenditure. The budgeted recurrent expenditure declines sharply in 2012, reflecting the reduction in goods and services expenditure, including the fuel purchase expenses following the corporatization of the Electricity Department in August 2011. In addition and in line with our commitments under the program, the 2012 budget freezes the wage bill, and continues to constrain the growth of expenditure on goods and services. While the overall capital expenditure is projected to increase (1.7 percent of GDP) due to the start of a grant-financed project, other capital expenditures remain largely in line with the 2011 estimates. As a result, total expenditure is expected to decline by 3.5 percentage points of GDP.

\section{In addition, we have identified specific contingent measures to meet program}

targets, if needed. These include: (i) ensuring that customs duty and customs service charge concessions are in line with the law (0.3 percent of GDP); (ii) beginning to phase out subsidies on LPG, while protecting the most vulnerable groups ( 0.1 percent of GDP), and (iii) a reduction in capital expenditure relative to the approved 2012 budget ( 0.6 percent of GDP). With these measures, we will ensure that the fiscal program is financed in a sustainable manner, while reducing expenditure arrears. 


\section{Fiscal reforms}

10. We will continue to enhance our in-house capability to manage public expenditure. With CDB's assistance, we will continue to strengthen our Public Sector Investment Program (PSIP) and our capability to evaluate projects.

11. We will continue to enhance our control over expenditure commitments. To control expenditure, we intend to strengthen our procurement regulation and the Ministry of Finance will carefully review proposals to increase spending before they are submitted to Cabinet. To avoid accumulation of arrears, we will seek further technical assistance from CARTAC in public expenditure management.

12. We will redouble our efforts to improve fiscal transparency. In this context, we will disseminate quarterly information on the overall fiscal situation and gross financing needs starting July 2012. We remain committed to ensuring that all expenditures are reported in the budget and that the newly established Electricity Company can adjust tariffs to recover its operating costs.

13. We are improving our capability to monitor economic developments and program performance. We have established a system for quarterly monitoring of belowthe-line financing of the central government's overall balance, and will update this on a quarterly basis. To this end, we will ensure the consistency of Ministry of Finance and ECCB data on the position of the government with the banking system.

\section{B. Other Program-Related Issues}

\section{We intend to launch the debt offer in the first quarter of 2012. Although} discussions with creditors have at times been complex, a clear consensus has emerged for those restructuring terms that are needed to place our debt on a sustainable footing. We remain committed to engaging our creditors, both external and domestic, in good faith negotiations, with a view to completing the debt exchange during the first quarter of 2012. Regarding collateralized domestic debt, key elements of the design of the debt-land swap program have been resolved [and the structure of the SPV has been agreed.] We expect to submit a draft proposal for the establishment of the SPV by June 2012.

15. The financial sector continues to be healthy. Financial soundness indicators suggest that the banking sector remains liquid and well capitalized. As a result, we do not envisage that the BSRF will be tapped for bank support. It will merely serve as an insurance policy. Consistent with the IMF's safeguards policy requirement and current practice, we will maintain all foreign exchange balances at the ECCB.

16. Prior actions and structural benchmarks. The delayed structural benchmark to update the registry and undertake valuation of the remaining 52 acres of land, update bank stress tests, and the approval of a 2012 budget consistent with program commitments are all 
prior actions for Board consideration of the first review. They have since been completed. The structural benchmark on reviewing the borrowing capacity of public enterprises is on track to be met by end-December 2011. Quarterly updates of banking sector stress tests by the ECCB and the registration of an additional 600 acres of land to facilitate the debt restructuring process are new quarterly benchmarks under the program for end-June 2012.

Table 1. St. Kitts and Nevis: Schedule of Review and Purchases

\begin{tabular}{|c|c|c|c|}
\hline \multirow[b]{2}{*}{ Availability date } & \multicolumn{2}{|c|}{ Amount of Purchase } & \multirow[b]{2}{*}{ Conditions } \\
\hline & Millions of SDR & Percent of Quota & \\
\hline July 27,2011 & 22.150 & 248.9 & Approval of arrangement \\
\hline November 15, 2011 & 11.470 & 128.9 & First review and end-September 2011 performance criteria \\
\hline February 15, 2012 & 3.161 & 35.5 & Second review and end-December 2011 performance criteria \\
\hline May 15, 2012 & 3.161 & 35.5 & Third review and end-March 2012 performance criteria \\
\hline August 15, 2012 & 3.161 & 35.5 & Fourth review and end-June 2012 performance criteria \\
\hline November 15, 2012 & 3.161 & 35.5 & Fifth review and end-September 2012 performance criteria \\
\hline February 15, 2013 & 1.105 & 12.4 & Sixth review and end-December 2012 performance criteria \\
\hline May 15, 2013 & 1.105 & 12.4 & Seventh review and end-March 2013 performance criteria \\
\hline August 15, 2013 & 1.105 & 12.4 & Eight review and end-June 2013 performance criteria \\
\hline November 15, 2013 & 1.105 & 12.4 & Nineth review and end-September 2013 performance criteria \\
\hline February 15, 2014 & 0.913 & 10.3 & Tenth review and end-December 2013 performance criteria \\
\hline May 15, 2014 & 0.913 & 10.3 & Eleventh review and end-March 2014 performance criteria \\
\hline Total & 52.510 & 590.0 & \\
\hline
\end{tabular}

Table 2. St. Kitts and Nevis: Quantitative Performance Criteria and Indicative Targets, 2011-12 (In millions of Eastern Caribbean dollars)

\begin{tabular}{|c|c|c|c|c|c|}
\hline & \multicolumn{3}{|c|}{ Performance Criteria } & \multicolumn{2}{|c|}{ Indicative Targets } \\
\hline & $\begin{array}{l}\text { End-Dec. } \\
2011\end{array}$ & $\begin{array}{l}\text { End-Mar. } \\
2012\end{array}$ & $\begin{array}{l}\text { End-Jun. } \\
2012\end{array}$ & $\begin{array}{l}\text { End-Sep. } \\
2012\end{array}$ & $\begin{array}{l}\text { End-Dec. } \\
2012\end{array}$ \\
\hline \multicolumn{6}{|l|}{ Performance Criteria: } \\
\hline Central government overall balance including grants (floor) $1 / 2 /$ & -60 & -24 & -53 & -91 & -60 \\
\hline Stock of central government budget expenditure arrears accumulation (ceiling) $3 /$ & 0 & 0 & 0 & 0 & 0 \\
\hline Stock of external short term debt (ceiling) & 0 & 0 & 0 & 0 & 0 \\
\hline $\begin{array}{l}\text { Central government or guaranteed external arrears accumulation (ceiling) } 4 \text { / } \\
\text { Indicative Target: }\end{array}$ & 0 & 0 & 0 & 0 & 0 \\
\hline Central government primary balance (floor) $1 / 2$ / & 76 & 7 & 19 & 8 & 68 \\
\hline
\end{tabular}

$1 /$ Cumulative within each calendar year.

2/ See the TMU for a description of adjustors.

$3 /$ The stock of arrears related to the fuel purchase is being audited by international auditors and the authorities are in the process of reconciliation.

4/ To be monitored on a continuous basis. 
Table 3. St. Kitts and Nevis: Performance and Proposed Prior Actions for the First Review and Structural Benchmarks 1/

Action
I. Structural Benchmarks for the First Revie
Update the registry of at least 600 acres of land
Undertake a valuation of at least 600 acres of land
Make substantial progress on the consultative phase of restructuring with creditors
Submit the bill for the corporatization of the Electricity Department to Parliament
Update the existing stress tests of financial institutions
II. Prior Actions for the First Review
Update the registry of the remaining 52 acres of land
Undertake a valuation of the remaining 52 acres of land
Update the existing stress tests of financial institutions
Parliament to approve a 2012 budget consistent with program commitments
Update the registry of additional 600 acres of land
Undertake valuation of additional 600 acres of land
Update the existing stress tests of banks

IV. Fiscal and Public Sector Reforms

\section{Public financial management}

Submit to Cabinet proposal to rationalize the subsidy on liquefied petroleum gas (LPG) Submit draft of new Procurement Act to Parliament

Draft proposal for the establishment of an asset management company

Establish a medium-term expenditure framework with agreed fiscal targets

Civil service reform

Cabinet to approve a plan for civil service reform covering human resource policy, reviewing the organization and structure of the civil service and addressing wage policy and payroll management

Actuarial review of Social Security

Regular review of the Social Security Scheme.

Public enterprise reform

Review borrowing capacity of public enterprises

Rationalize public land sales and development agencies

Strengthen social safety net

Submit social safety net reform strategy to Cabinet

v. Medium-term benchmark

Develop and explicit medium-term debt management strategy that takes account of the cost-risk tradeoff of alternative financing options, within the context of the overall macroeconomic environment

Draft proposal for a comprehensive pension reform

Sources: St. Kitts and Nevis authorities; and Fund staff.

$1 /$ Referenced as table 4 in Attachment II.
End-September 2011

End-September 2011

End-September 2011

End-September 2011

End-September 2011

End-December 2011

End-December 201

End-December 2011

End-December 2011

End-June 2012

End-June 2012

To be monitored on a quarterly basis

End-March 2012

End-June 2012

End-June 2012

End-June 2012

End-June 2012

Strenghten public financial management

End-September 2012

End-December 2011

Strenghten public financial management

End-September 2012 Strenghten public financial
management

End-March 2012 Streamline social safety nets

to accompany the 2013

Budget

End-June 2013
Improve medium-term orientation of the budget

Strenghten public financial management
Partially met Partially met

$\checkmark$

$\checkmark$ 


\section{AtTaChment II. TeChnical Memorandum OF Understanding}

1. St. Kitts and Nevis' performance under the Stand-By Arrangement (SBA) will be assessed on the basis of the quantitative performance criteria and indicative targets, as well as the structural benchmarks. This Technical Memorandum of Understanding (TMU) defines the variables set out in Table 2 of the Memorandum of Economic and Financial Policies (MEFP). It also lays down the reporting requirements to adequately monitor the program.

2. For the purposes of the program, the exchange rate of the East Caribbean dollar (EC\$) to the U.S. dollar is set at EC $\$ 2.70=$ US\$1. Foreign currency accounts denominated in currencies other than the U.S. dollar, excluding SDRs, will be first valued in the U.S. dollar at actual end-of-period exchange rates used by the ECCB to calculate the official exchange rates. SDR-denominated accounts will be valued at the program exchange rate of U.S. dollar 1.6 per SDR.

\section{Coverage}

3. For the purpose of the program, central government will cover all items included in the government budgets of the Federation (both St. Kitts and Nevis).

4. The nonfinancial public sector is defined as the total central government and nonfinancial public enterprises. Public enterprises consist of the Development Bank of St. Kitts and Nevis, Financial Services Regulatory Commission, Frigate Bay Development Corporation, La Vallee Greens Ltd, National Housing Corporation, Nevis Air and Sea Port Authority, Nevis Cultural Development Foundation, Nevis Electricity Corporation, Nevis Housing and Land Development Corporation, Nevis Solid Waste Management Authority, Nevis Tourism Authority, St. Christopher and Nevis Solid Waste Management Corporation, St. Christopher Tourism Authority, St. Kitts Urban Development Corporation, St. Christopher Air and Sea Ports Authority, WhiteGate Development Corporation, and ZIZ Broadcasting Corporation.

5. External debt is defined as all debt owed to creditors residing outside of St. Kitts and Nevis, while domestic debt covers all debt owed to residents of St. Kitts and Nevis. The latter covers all T-bills, including those held by creditors residing outside of St. Kitts and Nevis, and the bond issued at the Regional Government Securities Market (RGSM).

\section{Quantitative Performance Criteria}

\section{A. Central Government's Overall Deficit (PC)}

6. The central government overall balance will cover all of its revenue, grants, expenditure, and transfers. Revenues will exclude any proceeds from the sale of public assets such as land, which will be considered as financing below the line. Expenditures will exclude clearance of arrears, which will be considered as financing below the line. 
7. The central government's overall balance will be measured from the financing side as the sum of the net domestic financing, net external financing, plus proceeds from the sale of public assets, minus clearance of arrears.

8. Net domestic financing of the central government is defined as the sum of:

- $\quad$ net domestic bank financing as measured by the change in the domestic banking system credit to the central government net of deposits, as reported by the consolidated balance sheet of the monetary authorities and commercial banks, including special tranches from the ECCB;

- $\quad$ net nonbank financing as measured by the net changes in holdings of government securities by nonbanks, and net borrowing from nonbank institutions;

- the changes in the stock of domestic arrears of the central government defined as net changes in unpaid checks issued, unprocessed claims, pending invoices, plus accrued interest payments, and other forms of expenditures recorded above the line but not paid;

- $\quad$ gross receipts from divestment defined as proceeds received from any privatization, divestment, and sale of asset (land); and

- $\quad$ any exceptional financing, including rescheduled principal and interest.

9. Net external financing of the central government is defined as the sum of:

- $\quad$ disbursements of project and non-project loans, including securitization;

- $\quad$ proceeds from bonds issued abroad (with an original maturity of one year or greater);

- net changes in short-term external debt (with an original maturity of less than one year), excluding exceptional financing;

- net changes in cash deposits held outside the domestic banking system;

- $\quad$ any changes in arrears on external interest payments and other forms of external expenditures recorded above the line but not paid;

- $\quad$ any exceptional financing, including rescheduled principal and interest; 
- $\quad$ payments of principal on current maturities for bonds and loans on a due basis, including any prepayment of external debt.

10. The floor on the overall balance of the central government will be adjusted as follows:

- downward (i.e., a larger overall deficit target would apply) to the extent that budgetary grants fall short of the programmed amounts by less than EC\$3 million.

- upward to the extent that budgetary grants exceed the annual amounts specified in the program.

- downward by the cumulative amount of up to EC \$15 million spent on bank recapitalization and support to the British American Insurance Companies or CLICO as part of a regional solution - any amounts spent in excess of this programmed contingency will need to be funded within the program limit on the overall deficit.

- upward to the extent that clearance of arrears fall short of the amounts specified.

- upward to the extent of exceptional financing achieved through debt restructuring.

Table 1. Programmed Disbursements of Budgetary Grants in 2012 (in EC\$ millions)

\begin{tabular}{|c|c|c|c|c|c|}
\hline & Quarters & I & II & III & IV \\
\hline Grants & & 0.0 & 0.0 & 0.0 & 27.4 \\
\hline
\end{tabular}

Sources: St. Kitts and Nevis authorities; and Fund staff estimates. Note: Values presented are cumulative and Euro $1=$ US $\$ 1.3$.

\section{B. Stock of Central Government Short-Term External Debt (PC)}

11. The limit on short-term external debt applies to debt owed or guaranteed by the central government of St. Kitts and Nevis, with an original maturity of up to and including one year. Excluded from the limit are any rescheduling operations (including the deferral of interest on commercial debt) and normal import-related credits. Normal import credit is understood to be a self-liquidating operation where the proceeds from sales of imports are used to retire the debt. Debt falling within the limit shall be valued in U.S. dollars at the time of the contract or guarantee becomes effective. 


\section{External Arrears of the Public Sector (PC)}

12. The non-accumulation of arrears to external creditors will be a continuous performance criterion under the program. This performance criterion applies to arrears accumulated related to debt contracted or guaranteed by central government. External payment arrears consist of external debt service obligations (principal and interest) falling due after December 31, 2010 that have not been paid at the time due, taking into account the grace periods specified in contractual agreements. Arrears resulting from nonpayment of debt service for which a clearance framework has been agreed or a rescheduling agreement is being sought are excluded from this definition.

\section{Budget Expenditure Arrears (PC)}

13. A ceiling is set on central government budget expenditure arrears, equal to the stock of such arrears as at December 31, 2010 (Table 2). The ceiling applies to the increase in the sum of: (1) any invoice that has been received by a spending agency from a supplier of goods, services, and capital goods delivered and verified, and for which payment has not been made within the contractually agreed period, or in the absence of a grace period, within 60 days; and (2) unpaid wages, pensions, or transfers, pending for longer than 60 days to domestic or foreign residents, irrespective of the currency denomination of the debt. Interest and amortization arrears on domestic debt resulting from nonpayment of debt service for which a clearance framework has been agreed or a rescheduling agreement is being sought are excluded from this ceiling. For ease of monitoring, all debt issued on the Regional Government Securities Market (RGSM), irrespective of who holds it, will be regarded as domestic debt.

Table 2. Stock of Budget Expenditure Arrears at end-December, 2010 (in EC\$ millions)

\begin{tabular}{lr}
\hline Stock of arrears 1/ & 183 \\
Unpaid checks issued & $\ldots$ \\
Unprocessed invoices & $\ldots$ \\
Pending invoices & $\ldots$ \\
Interest and amortization arrears on domestic debt & 0 \\
& \\
Total & 183 \\
\hline Source: St. Kitts and Nevis authorities. & \\
1/ The stock of arrears related to the fuel purchase is being audited by & \\
international auditors and the authorities are in the process of reconciliation. &
\end{tabular}

\section{Indicative Target On the Primary Balance of the Central Government}

14. The central government's primary balance is defined as revenue and grants minus non-interest expenditures. As in the definition of the overall balance, revenue will exclude any proceeds from the sale of public assets. Net lending is a non-interest expenditure item 
(negative net lending is a revenue item). Interest expenditures include interest payments on outstanding arrears, as defined above in sections IIC and IID (at their contractual rates) converted to a cash basis.

15. The floor on the primary balance of the central government will be monitored from the financing side as the sum of the net domestic financing, net external financing, proceeds from the sale of public assets, plus domestic and external interest payments on a due basis.

16. The floor on the primary balance of the central government will be adjusted as follows:

- downward (i.e., a smaller primary surplus target would apply) to the extent that budgetary grants fall short of the programmed amounts by less than EC\$3 million.

- upward to the extent that budgetary grants exceed the annual amounts specified in the program.

- downward by the cumulative amount of up to EC\$15 million spent on bank recapitalization and support to the British American Insurance Companies or CLICO as part of a regional solution.

- upward to the extent of exceptional financing achieved through debt restructuring.

\section{DATA AND INFORMATION}

17. To enable monitoring of performance relative to the above quantitative performance criteria and indicative targets, the St. Kitts and Nevis authorities will provide Fund staff with the following specific data and information within 8 weeks after the end of each month.

\section{Fiscal sector}

- $\quad$ Central government budgetary accounts.

- $\quad$ Capital expenditure.

- $\quad$ Total monthly disbursements and grants receipts, disaggregated into: (a) budgetary support (by type - either loans, external "bonds" and/or other securities); (b) project loans; (c) budgetary grants; and (d) project grants.

- $\quad$ Central government domestic debt data (St. Kitts and Nevis). 
- $\quad$ Stock of domestic arrears, including unpaid checks issued, stock of unprocessed claims due and invoices pending; interest and amortization on domestic debt.

- $\quad$ Stock of external arrears by creditor.

- Detailed monthly external debt report from the Debt Unit in the Ministry of Finance, showing fiscal year-to-date disbursements, amortization, interest payments and outstanding stocks, for the central government and public enterprises.

- $\quad$ Copies of loan agreements for any new loans contracted, including financing involving the issue of government paper, and of any renegotiated agreements on existing loans.

\section{Financial sector}

- $\quad$ Monetary survey for St. Kitts and Nevis as prepared by the Eastern Caribbean Central Bank.

\section{Real sector}

- $\quad$ Consumer price index.

18. Reporting on a quarterly basis will include the following:

\section{Fiscal}

- A detailed overview of capital expenditures on a project by project basis and the composition of financing.

- $\quad$ Financial position of the public enterprises (as listed in paragraph 4).

\section{Real sector}

- Economic indicators under the real sector.

\section{External sector}

- Economic indicators under the external sector.

19. Reporting on an annual basis will include the following:

\section{External and real sectors}

- $\quad$ GDP and its components. 
- $\quad$ Balance of payments accounts.

20. Other reporting will include:

- $\quad$ Reports of legislative changes pertaining to economic matters.

- $\quad$ Notification of any establishment of new public enterprises.

- $\quad$ All disbursements and outstanding balances from the use of the Banking Sector Reserve Fund on a weekly basis. 


\section{ATTACHMENT III}

20 December, 2011

The Right Honourable Dr. Denzil L. Douglas

Prime Minister and Minister of Finance, Sustainable

Development and Human Resource Development

Government Headquarters

Church Street

BASSETERRE

St. Kitts

Dear Prime Minister:

Thank you for sharing with the Eastern Caribbean Central Bank (ECCB) the draft Memorandum on Economic and Financial Policies (MEFP) agreed with the mission from the International Monetary Fund during the first review under the Stand-By Arrangement. We note the policies outlined therein, towards placing St. Kitts and Nevis on a sustainable fiscal path, while further strengthening the financial sector.

In line with our previous discussions - and as laid out in the MEFP as structural benchmarks - the ECCB will conduct quarterly stress test for domestic commercial banks and share them with IMF staff, in line with current practices. We welcome the inclusion of this benchmark and will take the necessary steps for it to be observed within the time frame specified in Table 4 of the MEFP.

Please feel free to share this letter with the IMF in the context of the review of the Stand-By Arrangement.

Yours faithfully

$$
\text { /s/ }
$$

K Dwight Venner

Governor 
Press Release No. 12/27

International Monetary Fund

FOR IMMEDIATE RELEASE

Washington, D.C. 20431 USA

January 25, 2012

\section{IMF Executive Board Completes First Review Under Stand-by Arrangement with St. Kitts and Nevis}

The Executive Board of the International Monetary Fund (IMF) today completed the first review of St. Kitts and Nevis' economic performance under a program supported by a 36-month Stand-by Arrangement (SBA). The completion of the review allows the immediate disbursement of an amount equivalent to SDR 11.47 million (about US\$17.6 million), bringing total disbursements under the arrangements to SDR 33.62 million (about US\$51.6 million).

The SBA was approved on July 27, 2011 (see Press Release No. 11/295), for an amount equivalent to SDR 52.51 million (about US\$80.7 million), or 590 percent of St. Kitts and Nevis' IMF quota.

Following the Executive Board's discussion, Mr. Naoyuki Shinohara, Deputy Managing Director and Acting Chair, made the following statement:

“The St. Kitts and Nevis' economy is estimated to have remained flat in 2011 after two years of contraction, but the outlook remains favorable supported by Foreign Direct Investmentrelated construction projects and an improvement in tourism activities. Uncertainty regarding the global economic recovery, however, highlights increasing downside risks. Steadfast implementation of policies under the Fund-supported program will be important going forward.

"All end-September 2011 quantitative targets have been met, despite slower-than-expected economic growth. The fiscal target was met by a comfortable margin, and the authorities were successful in reducing budget expenditure arrears to below the levels at the end of December 2010. No external arrears were accumulated except for debt service payments, which are part of the debt restructuring. Also, the authorities approved the 2012 budget consistent with the program objectives. 
"The authorities have made progress on structural reforms, including by updating the registry and undertaking the valuation of 600 acres of land, as well as updating existing stress tests of financial institutions. To ensure fiscal sustainability, further reforms will focus on public financial management, the civil service, the social security system, and the strengthening of the social safety net.

"The authorities are making progress on negotiations with their creditors for the comprehensive restructuring of the public debt. Early implementation of the debt restructuring will be critical for the success of the program. Continued commitment to ensuring the stability and health of the financial sector will be important to reduce vulnerabilities," Mr. Shinohara said. 